\title{
Comprehensive energy, economic and thermal comfort assessments for the passive energy retrofit of historical buildings - A case study of a late nineteenth-century Victorian house renovation in the UK
}

\begin{abstract}
This paper aims to evaluate the energy-saving potential, affordability and thermal comfort performance of various passive building retrofit measures for a historical building (late nineteenthcentury Victorian house) renovation. Three types of interior passive retrofit measures (i.e. internal wall insulation, glazing upgrade and airtightness improvement), classified as traditional and advanced measures, are further grouped into 63 retrofit combinations. In order to evaluate the performance of these defined retrofit combinations, five assessment indicators are proposed, including energy reduction rate, specific initial cost, discounted payback period, space volume reduction rate, and indoor thermal comfort. Under three internal space reduction scenarios with a space reduction rate of $5.2 \%, 2.6 \%$ and $1.3 \%$, these combinations are evaluated and compared, and the most favourable combinations are determined to achieve multiple objectives (maximum energy saving, most cost-effective and most energy-efficient). The influence of the most favourable retrofit combinations on the internal thermal comfort level improvement is also dynamically evaluated using the EnergyPlus simulation tool. The final recommended passive retrofit combination consists of vacuum insulation windows, gypsum air infiltration reduction, and $2 \mathrm{~cm}$ thickness of Polyisocyanurate (PIR) panels, with $51.8 \%$ of primary energy reduction, a specific initial investment of $£ 144.71 / \mathrm{m}^{2}$ and a discounted payback period of 18 years.
\end{abstract}

\section{Keywords:}

Building Retrofit, Passive Measures, Historical Building, Space Volume reduction, Energy Consumption Reduction, Cost Effectiveness, Thermal Comfort. 


\section{Nomenclature:}

\begin{tabular}{|c|c|c|c|}
\hline U-value & Thermal transmittance $\left(\mathrm{W} / \mathrm{m}^{2} \mathrm{~K}\right)$ & ICDDs & $\begin{array}{l}\text { Insulated cooling degree days }\left({ }^{\circ} \mathrm{C} \cdot\right. \\
\text { days) }\end{array}$ \\
\hline Gx & Glazing insulation with code $x(x=1,23 \cdots 5)$ & \multicolumn{2}{|c|}{ Acronyms } \\
\hline Ey & $\begin{array}{l}\text { Envelope insulation with code y }(y=1,2 \\
3 \cdots 15)\end{array}$ & $\mathrm{ACH}$ & Air change rate per hour \\
\hline$\overline{A z}$ & $\begin{array}{l}\text { Airtightness improvement with code } z \\
(z=1,2,3,4)\end{array}$ & $\begin{array}{l}\text { ASHRA } \\
\mathrm{E}\end{array}$ & $\begin{array}{l}\text { American Society } \\
\text { Refrigerating and Air-Conditioning } \\
\text { Engineers }\end{array}$ \\
\hline $\mathrm{V}_{\mathrm{sr}}$ & space volume reduction rate (\%) & CIBSE & $\begin{array}{l}\text { Chartered Institution of } \quad \text { Building } \\
\text { Services Engineers }\end{array}$ \\
\hline$T_{r}$ & Room temperature $\left({ }^{\circ} \mathrm{C}\right)$ & EPC & Energy performance certification \\
\hline$T_{a m b}$ & Ambient temperature $\left({ }^{\circ} \mathrm{C}\right)$ & SAP & Standard Assessment Procedure \\
\hline$\theta_{s t d, h}$ & $\begin{array}{l}\text { Winter indoor heating comfort reference } \\
\text { temperature }\left({ }^{\circ} \mathrm{C}\right)\end{array}$ & DHW & Domestic hot water \\
\hline$\theta_{s t d, c}$ & $\begin{array}{l}\text { Summer indoor cooling comfort reference } \\
\text { temperature }\left({ }^{\circ} \mathrm{C}\right)\end{array}$ & PIR & Polyisocyanurate \\
\hline DPP & Discounted payback periods (years) & IES VE & $\begin{array}{l}\text { Integrated Environmental Solutions - } \\
\text { Virtual Environment }\end{array}$ \\
\hline SCPP & Specific cost payback periods (years/k£) & EPBD & $\begin{array}{l}\text { Directive on the energy performance of } \\
\text { buildings }\end{array}$ \\
\hline IHDDs & Insulated heating degree days $\left({ }^{\circ} \mathrm{C} \cdot\right.$ days $)$ & low-E & Low emissivity \\
\hline
\end{tabular}

\section{Introduction}

\subsection{Background}

Under the Paris Agreement [1], The European Commission has set up a clear target to reduce at least $40 \%$ of the greenhouse gas by 2030 and achieve carbon neutrality by 2050 [2]. The UK government has also set up its target to bring all greenhouse gas emissions to be net-zero by 2050 [3]. Improving energy efficiency is one of the most crucial strategies to achieve this target [4].

Buildings consume more than $40 \%$ of all energy used in the EU. In the UK, energy consumption in domestic building accounts for about $30 \%$ of Britain's total energy budget, and $20 \%$ of UK greenhouse gas emissions. Building retrofit represents one of the most energy-efficient and affordable pathways to meet common climate goals.

According to the European Commission [5], around 80 to $85 \%$ of the existing buildings will still be in use in 2050. However, in Europe, the current building retrofits are implemented at a very low rate 
(i.e., 1.2\% per year), with even lower demolition rates (i.e., $0.1 \%$ per year) [5]. According to English Housing Survey [6], more than half $(57 \%)$ of the UK's homes were built before 1965 , making the building stock in the UK less energy efficient with high carbon emission compared with other European countries [7]. The Committee for Climate Change in 2019 determined that a 15\% reduction in domestic energy is required by 2030 to reach a net zero target in 2050 [8]. The life cycle costs in

[9] show that costs are higher for demolition and rebuilding of older dwellings compared to retrofitting to the same energy standards, without even considering the obvious increase in emissions associated with demolition and rebuild, which is undesirable given the 2050 target of net zero emissions within the UK. As such, retrofitting of dwellings to upgrade them to be more energy efficient is a desirable option. The selection of proper building retrofit combinations can provide critical information to assit the home owners and landlords to make robust decisions that not only reduce energy consumption and minimize carbon emissions over the long-term, but also lead to the improvement of indoor health and wellbing standard, thereby paving the way for the conventional building sector towards a carbon-neutral and resilient society in the near future, both in the UK and worldwide.

\subsection{Literature review}

Compared with traditional buildings, the historical building renovation is even more challenging, as the selection and application of building retrofit measures need to be done carefully, in order to maintain the building's unique architectural appearance and integrity [10]. According to Whitman et al. [11], buildings constructed before 1919 in the UK could be considered as a historical building, exhibiting special architectural features and cultural/historical values. As shown in Fig. 1, a total of 24.2 million dwellings exist in the UK, with around $20.5 \%$ constructed before 1919 . In this research, a typical Victorian house [12] in Nottingham (United Kingdom), which was built in the 1880s, is chosen as the case study building. The character of such historical buildings should be respected and preserved to a great extent. A proper balance between the energy efficiency improvement and the historical building conservation needs to be considered when applying building renovations [10]. 
A wide range of building renovation measures have been adopted in a large number of studies on historical building renovations, focussing on reduced energy consumption [13-16] and smart technologies/system integration $[17,18]$. Two case study models were established by Ciulla et al. [19] under four different climatic conditions (Roma, Milano, Cagliari and Palermo) in Italy. For each case, eight retrofit measures including building fabric thermal insulation and window upgrade were simulated in EnergyPlus. The results revealed that the proper combination of retrofit measures could bring the energy-saving up to $30 \%$, with costs between $214-300 € / \mathrm{m}^{2}$. However, it is still quite challenging to define and apply an array of appropriate building retrofit measures for historical building renovations, in order to maintain the building's integrity and in the meanwhile, achieve a higher level of indoor thermal comfort. Moreover, from the homeowners' perspective, their decisions on building renovations are not only related to potential energy-saving and associated cost-benefit. More often, they will be motivated to undertake building renovation if it proves to provide increased thermal comfort and indoor living conditions. Under this context, a range of "Passive retrofit measures" [20] is defined in this research, with particular focus on improving the existing building envelope thermal performance through additional thermal mass to the interior wall, window upgrade and airtightness improvements, etc.

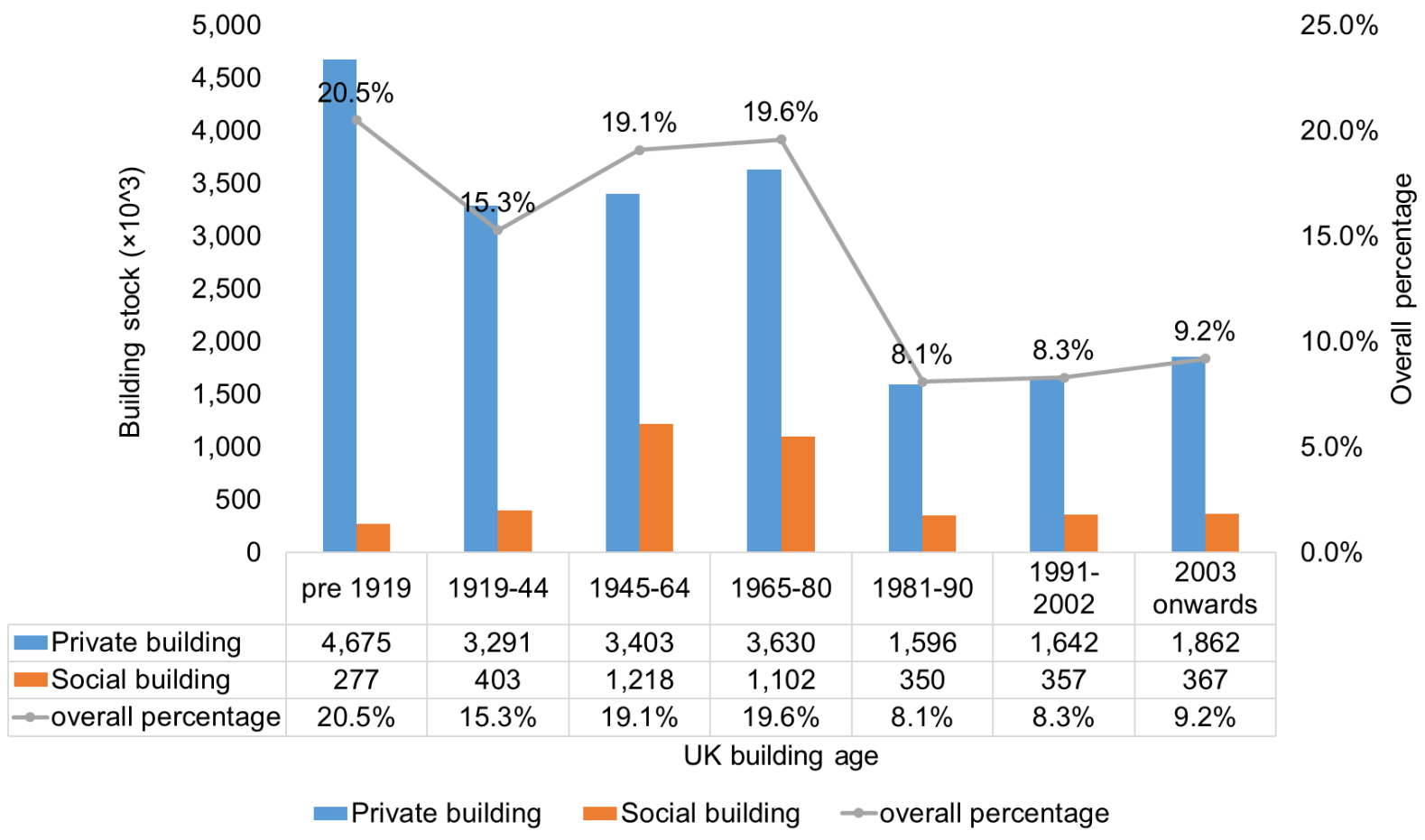


Fig. 1 UK existing building stock classified based on construction year [6]

Recent years have seen great advances in the development of innovative materials and products (such as aerogel-based aggregate coatings [21-23] and vacuum insulation panels [22, 24, 25]), with superior thermal performance and occupying less space, whose performance is extremely valuable in building renovation. Biswas et al. [26] evaluated numerically and experimentally the energy-saving potential of applying vacuum insulation panels (VIP) onto the exterior wall for a single-story building in a cold climate. The variations of heat flow for both pre-retrofit and post-retrofit scenarios were compared, with heat energy saving around $46 \%$. Apart from building facade retrofit, existing window glazing upgrading [27] and airtightness improvement are also recognised as essential methods to enhance the building thermal performance.

Several multi-criteria retrofit assessment methods have been analysed by researchers [28-30], focussing on the primary energy saving and economic assessment [31-34]. Energy-saving and life cycle analysis of alternative passive building retrofit measures were performed by Rodrigues et al. [35], to investigate the trade-off between the investment costs and the renovation efficiency. Occupancy energy usage profiles, which has a crucial impact on the building energy consumption, was categorised as office, low and high residential usage to facilitate the analysis. The authors concluded that around $8-32 \%$ life cycle cost reduction could be achieved. A multi-objective optimisation method was proposed by Wang et al. [36] to investigate the thermal performance improvement of building retrofit measures such as additional insulation for external wall and roof, airtightness improvement and window shading. The optimisation results indicated an annual energy saving of $86.7 \%$ could be acheived, with $63.0 \%$ thermal comfort improvement.

Table 1 summarises the previous research outcomes on building renovations. It could be found out that there is only a limited number of studies concentrating on historic building renovations. The majority of such research works evaluated the passive building retrofit measures (i.e. wall insulation, glazing insulation, airtightness improvement) separately, without holistically analysing their possible combinations and the associated impacts. From the homeowners and investors' perspectives, their decisions on building renovations are not only guided by potential energy-saving and associated 
cost-benefit but also closely linked with the indoor comfort level improvement. However, hardly any research has attempted to tackle the challenge of historical building renovation by defining a sustainable and holistic retrofit strategy from the comprehensive perspectives of energy, cost and thermal comfort. Therefore, it is significantly crucial to investigate and define the optimal energy renovation measures for historical building retrofit, by adopting a comprehensive approach, taking energy consumption into considerations, as well as cost-effectiveness and the impact on historical building integrity and thermal comfort level.

Table 1 Summary of previous studies on building renovation applying passive retrofit measures

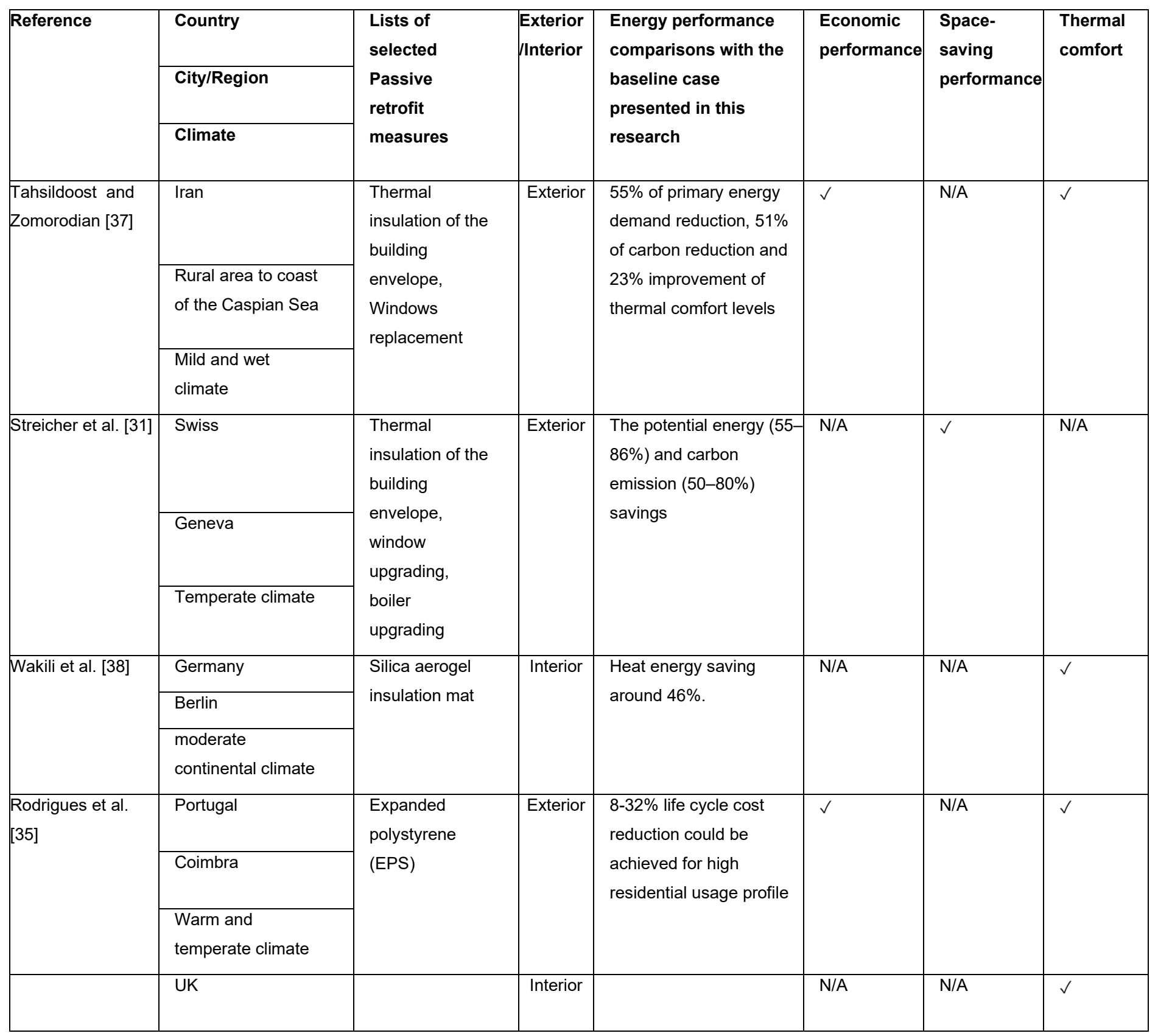




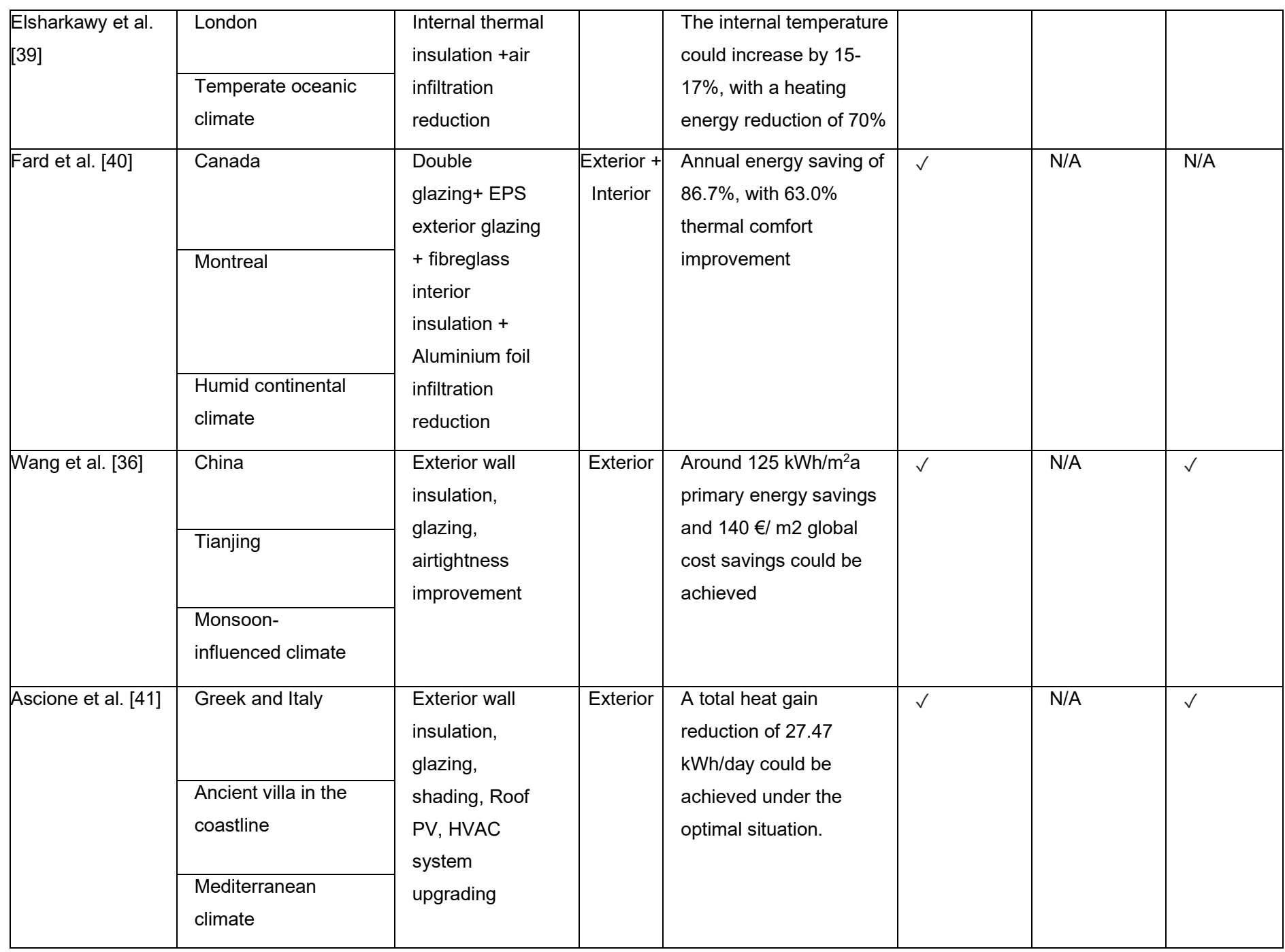

\subsection{Research objectives}

This paper proposes a comprehensive approach for historical building renovation with a presentation of a fundamental pathway towards deep renovations [7] which could lead to a 'highly efficient and decarbonised, nearly Zero-Energy Building stock by 2050'. The objectives of this research are listed below:

1) to define a series of passive building retrofit measures (insulation, glazing upgrading and airtightness improvement) and their potential combinations for a historical building renovation (a typical $19^{\text {th }}$-century Victorian house), in order to maintain its integrity. These passive retrofit measures will also be grouped into advanced and traditional measures, in order to assess and compare their own benefits from energy, costs and internal space reduction points of view. 
2) to evaluate the level of energy-saving and economic benefits and determine the optimal retrofit combinations under three levels of defined optimisation categories.

3) to perform the indoor thermal comfort level analysis for the selected optimal retrofit combinations.

\section{Methodology}

In order to perform a comprehensive assessment of the typical historical building renovation, the following research methodology (shown in Fig. 2) has been applied:

1) Definition of the case study building and characterisation of its envelope and systems (section 2.1);

2) Establishment of the baseline model and occupancy profile (section 2.2) and obtain the initial annual building energy consumptions for the baseline scenario (section 2.3);

3) Definition of passive retrofit measures (section 2.4), the classification of advanced and traditional retrofit measures (section 2.5);

4) Establishment of technical variants and combinations (section 2.3) for energy performance assessment and the determination of the most optimal combinations (section 2.5);

5) Cost-optimal and comprehensive energy analysis by defining three optimisation categories (section 2.6).

6) Indoor thermal comfort analysis for summer and winter conditions, based on the selected optimal combinations (section 3.3).

By the processes outlined above, this paper will aim to investigate the following research topics:

1) What will be the maximum energy saving potential for the selected advanced and traditional retrofit combinations when the indoor space volume reduction is within $5.2 \%, 2.6 \%$ and $1.3 \%$ ?

2) Will the majority of the chosen retrofit combinations be able to achieve "Deep Renovation" [42], which means at least $60 \%$ energy reduction compared with the baseline scenario.

3) Will it be more cost-effective when adopting advanced passive retrofitting measures than traditional passive measures? 
4) For a typical Victorian house in the UK climate, how would the implementation of the proposed passive retrofit measures affect the indoor comfort level?

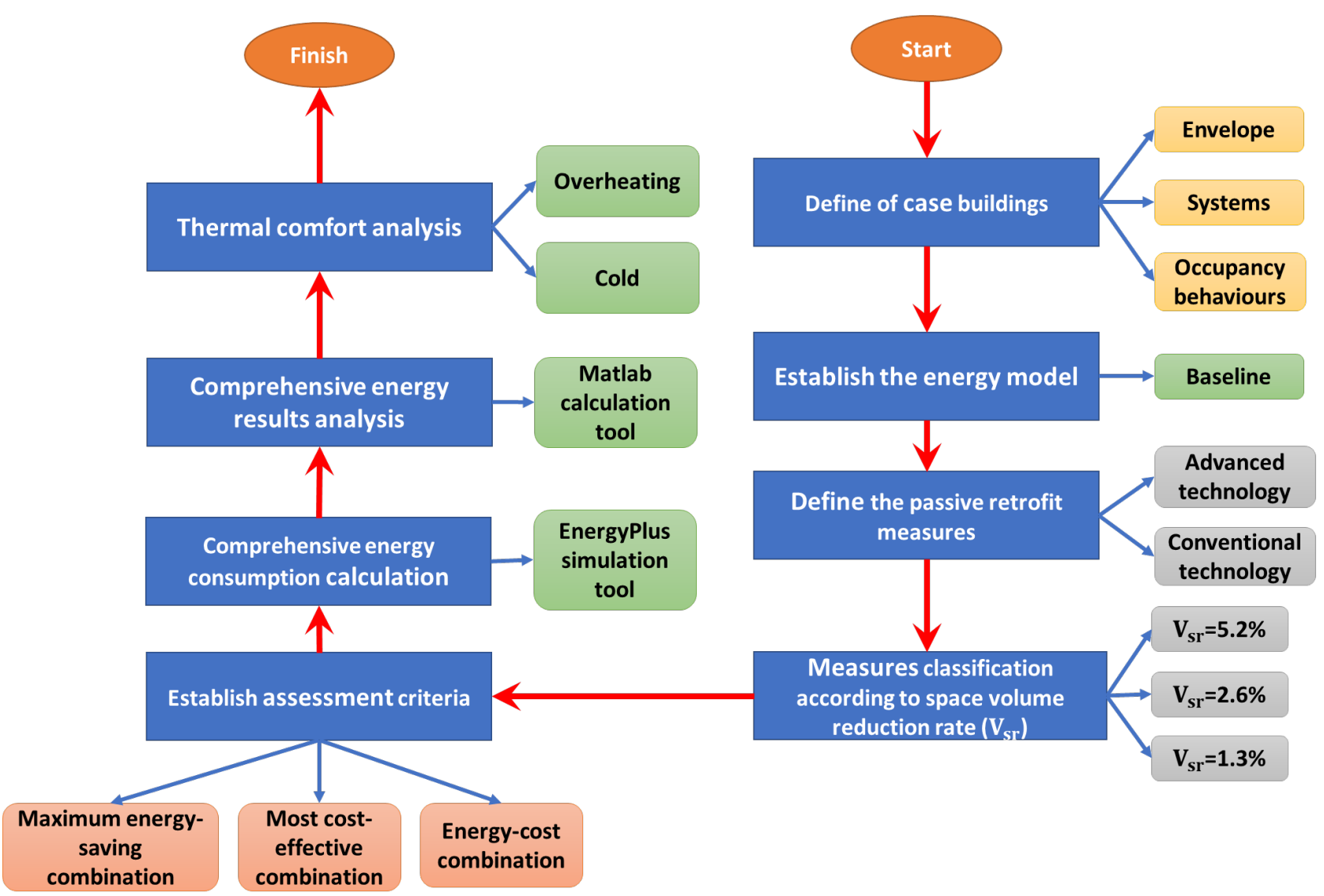

Fig.2 Flow chart of the methodology

\subsection{Case study building description}

The case study building-Paton House is a typical representation of a $19^{\text {th }}$-century Victorian-style house, which was normally constructed in the periods of 1820-1900s. Located in the suburb of Nottingham, UK, Paton house is a three-story detached dwelling house with a total floor area of $1014.22 \mathrm{~m}^{2}$ and space volume of $3328 \mathrm{~m}^{3}$. Built in 1884, the building is featured with its red solid brick wall, the traditional wooden frame roof, and its large canopy over the entrance, representing the typical features of the Victorian houses. Fig. 3 shows the images of the north and south facades of Paton House. The details of building construction materials and thermal physical characters are summarised in Table 2. Paton house in its current condition has shown poor energy performance as well as low comfort level, which could hardly meet the building decarbonisation target set out by the 
UK government. Therefore, it is crucial to look for innovative and cost-effective passive interior retrofit measures to improve its thermal performance.

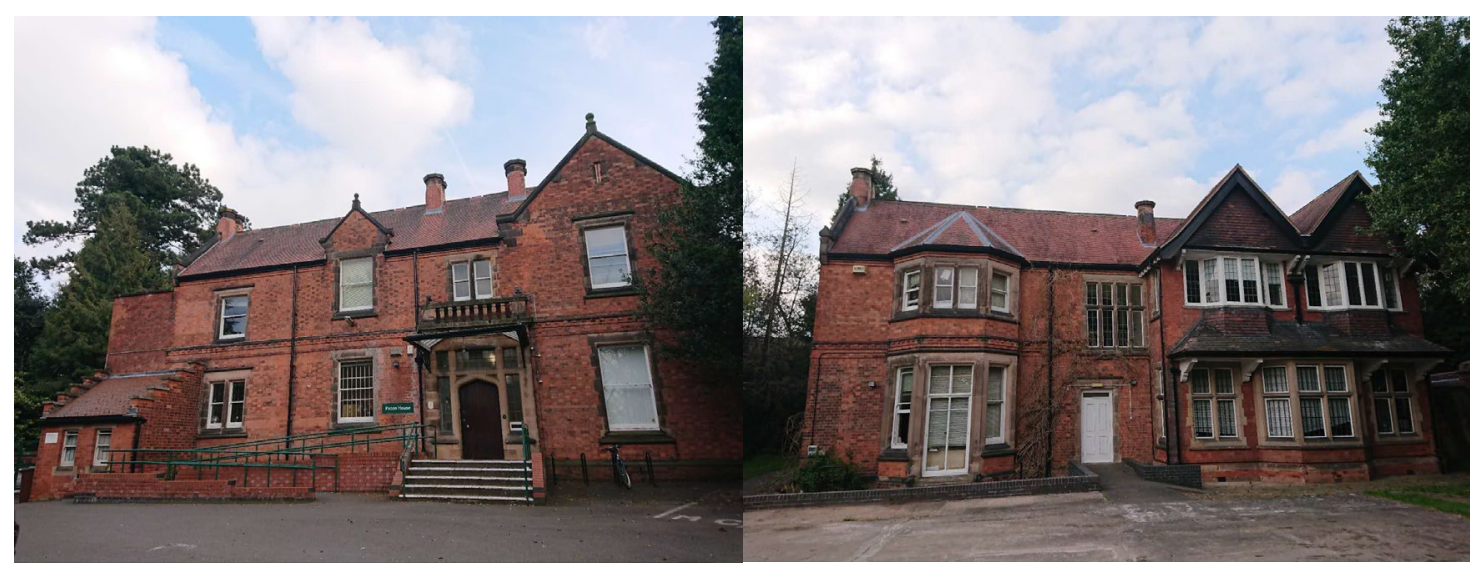

(a) North façade - Front view

(b) South façade - Back view

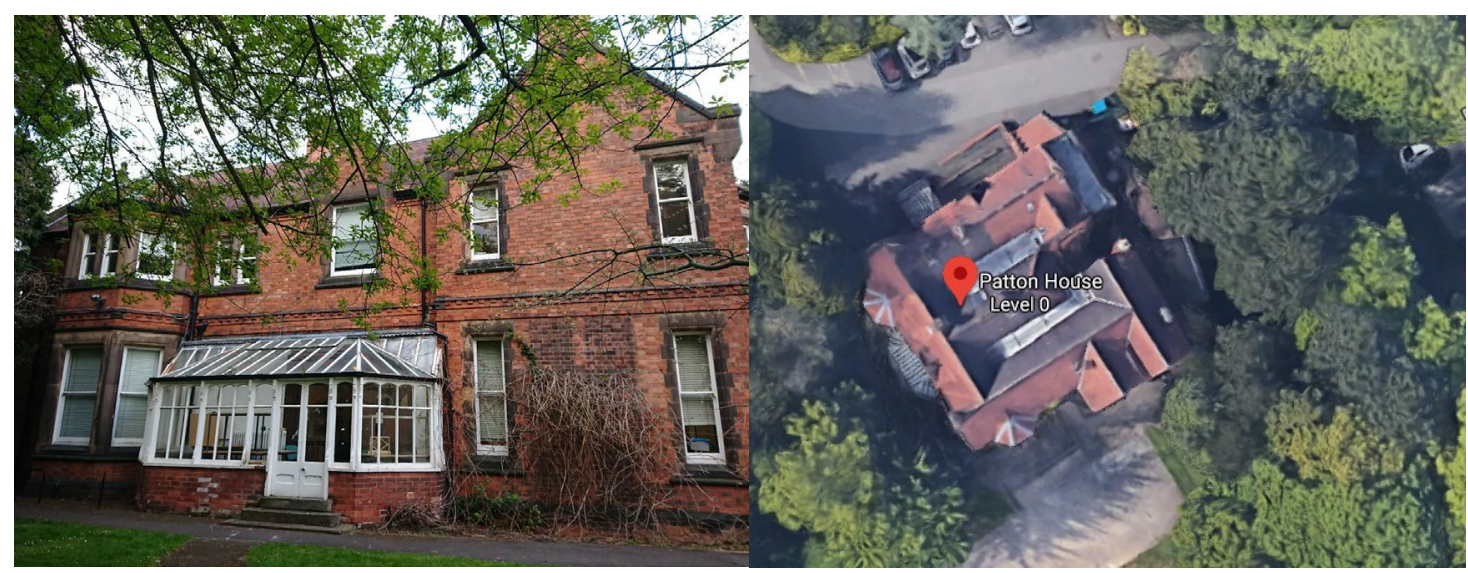

(c) West facade - Side view

(d) Top view (from google map)

Fig.3 Façade images and top view of Paton House

Table 2 Building construction materials

\begin{tabular}{|c|c|c|c|c|c|}
\hline $\begin{array}{l}\text { Building } \\
\text { components }\end{array}$ & Materials & $\begin{array}{l}\text { Conductivity } \\
(\mathrm{W} / \mathrm{mK})\end{array}$ & $\begin{array}{l}\text { Density } \\
\left(\mathrm{kg} / \mathrm{m}^{3}\right)\end{array}$ & $\begin{array}{l}\text { Specific heat } \\
\text { capacity } \\
(\mathrm{J} / \mathrm{kgK})\end{array}$ & $\begin{array}{l}\text { Overall } \mathrm{U} \text { - } \\
\text { value }\left(\mathrm{W} / \mathrm{m}^{2} \mathrm{~K}\right)\end{array}$ \\
\hline \multirow[t]{2}{*}{ Ground floor } & $\begin{array}{l}400 \mathrm{~mm} \text { cast } \\
\text { concrete }\end{array}$ & 1.13 & 2000 & 1000 & \multirow{2}{*}{1.18} \\
\hline & $\begin{array}{l}100 \mathrm{~mm} \text { air space } \\
\text { resistance }\end{array}$ & \multicolumn{3}{|c|}{ Thermal resistance: $0.15 \mathrm{~m}^{2} \mathrm{~K} / \mathrm{W}$} & \\
\hline
\end{tabular}




\begin{tabular}{|c|c|c|c|c|c|}
\hline & $\begin{array}{l}20 \mathrm{~mm} \text { timber } \\
\text { floor }\end{array}$ & 0.14 & 650 & 2300 & \\
\hline & 10mm carpet & 0.05 & 1.70 & 200 & \\
\hline \multirow[t]{2}{*}{ Exterior wall } & 300mm brick & 0.84 & 1700 & 800 & \multirow{2}{*}{2.53} \\
\hline & 19mm gypsum & 0.50 & 1300 & 1000 & \\
\hline \multirow[t]{3}{*}{ Exterior roof } & $19 \mathrm{~mm}$ Clay tiles & 0.71 & 1200 & 1380 & \multirow{3}{*}{1.28} \\
\hline & $\begin{array}{l}\text { 100mm timber } \\
\text { joist }\end{array}$ & 0.14 & 650 & 1200 & \\
\hline & 19mm gypsum & 0.50 & 1300 & 1000 & \\
\hline $\begin{array}{l}\text { Exterior } \\
\text { window }\end{array}$ & $\begin{array}{l}\text { 3mm single } \\
\text { glazing }\end{array}$ & 0.02 & & & 5.80 \\
\hline Exterior door & $\begin{array}{l}\text { 44mm timber } \\
\text { door }\end{array}$ & 0.17 & 650 & 2300 & 3.86 \\
\hline
\end{tabular}

\subsection{Baseline building model establishment}

An energy simulation model for the baseline building was built in the EnergyPlus (Version 8.7.0) simulation tool [43]. The primary energy source of the baseline building is considered as two partselectricity and natural gas, which are respectively used for appliance and space heating purpose. The occupancy profile for a typical academic office building [44-46] is assumed and applied to conduct the simulation. As shown in Fig. 4, the building is assumed to be functioning mostly during weekdays with the maximum design capacity of 131 people. The electricity consumption for lighting is assumed to be $0.76 \mathrm{~W} / \mathrm{m}^{2}[47,48]$. The lighting schedule is shown in Fig.5. The schedule scale is varied in the range of 0 to 1 : "1" indicating the maximum load for occupancy numbers or lighting power, and "0" for schedule off (i.e., with no people inside and no lighting turned on). 


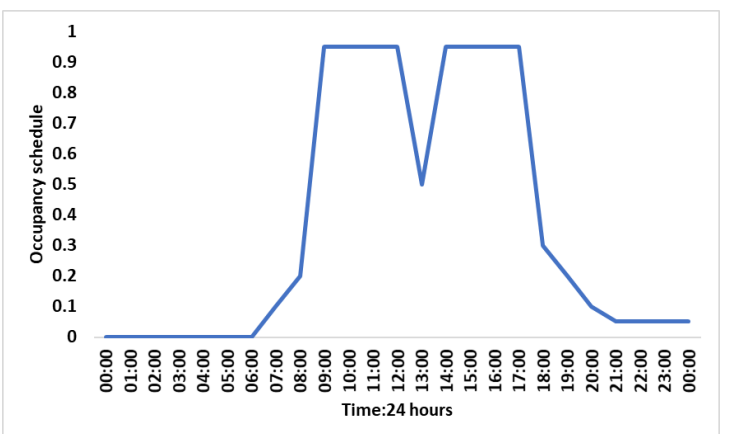

(1) Occupancy schedule - weekdays

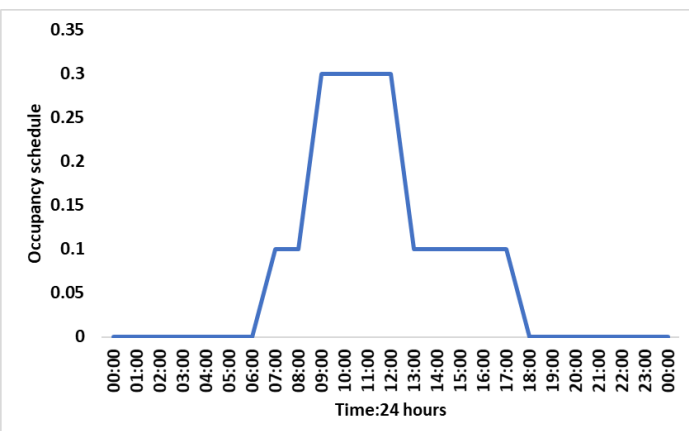

(2) Occupancy schedule - weekends

Fig.4 Occupancy schedules

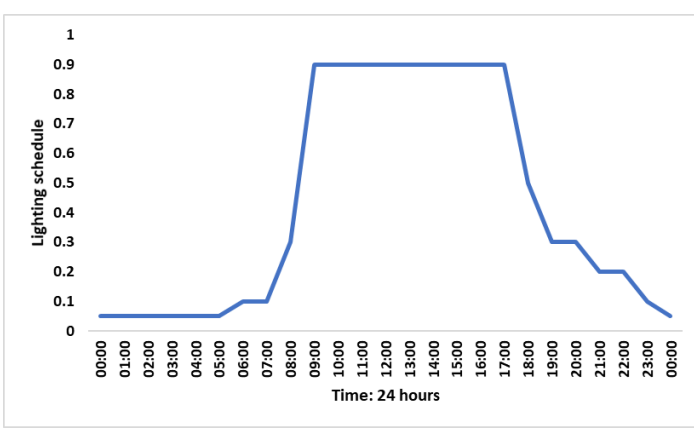

(1) Lighting schedule - weekdays

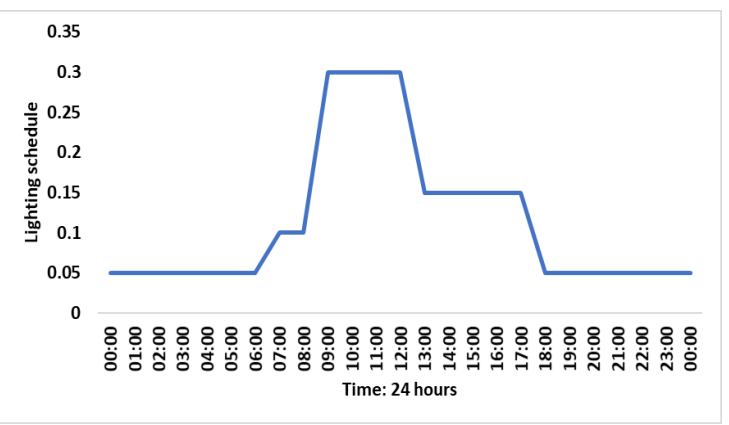

(2) Lighting schedule - weekends

Fig.5 Lighting schedules

In order to satisfy the indoor thermal comfort, the winter indoor temperature is set as $20^{\circ} \mathrm{C}$, from $15^{\text {th }}$ October to $15^{\text {th }}$ March, which is supplied by radiators and connected with a hot water boiler. Since no cooling system is installed in Paton House, the summer indoor temperature will fluctuate according to the actual selection of retrofit measures. The baseline building simulation is conducted according to the following input parameters defined from ASHRAE and CIBSE guides: the airtightness of the building is assumed as a whole with $15.2 \mathrm{ACH}$ under the $50 \mathrm{~Pa}$ [49], which is equal to $0.76 \mathrm{ACH}$ infiltration rate (calculated based on [50]). The weather profile of Nottingham is acquired from the data from EnergyPlus. The baseline geometry plan for the two floors are shown in Fig. 4. The model is firstly generated in SketchUp and then inputted to the EnergyPlus simulation software, as shown in Fig.5. 


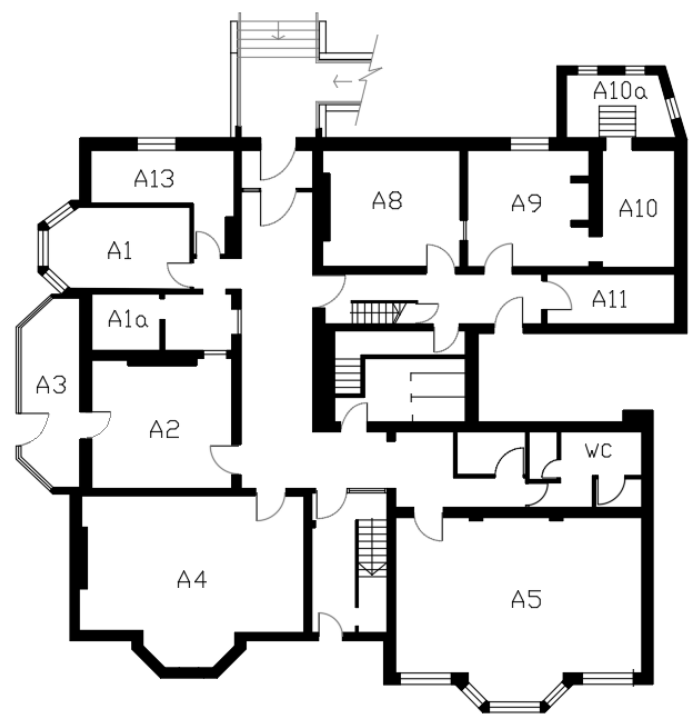

(1) Ground floor geometry plan

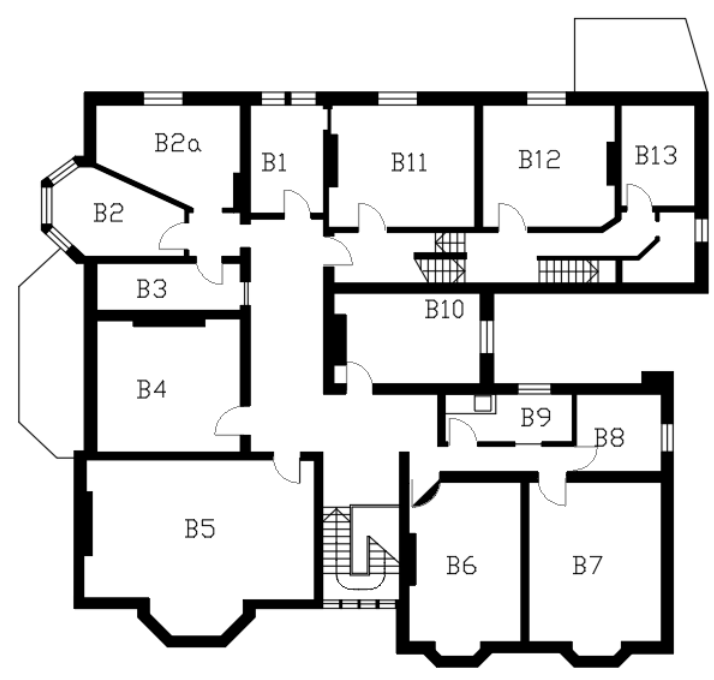

(2) First floor geometry plan

Fig.4 Baseline geometry plan

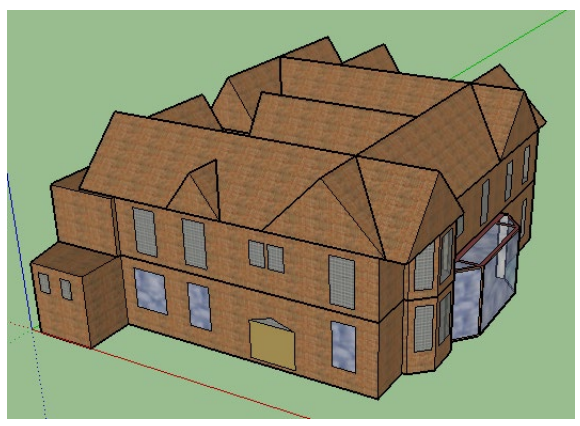

(1) 3D model view from north-west side

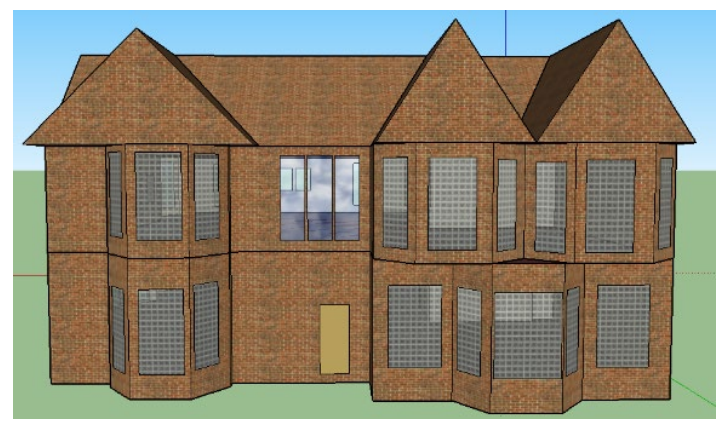

(2) 3D model view from south side

Fig. 5 Virtual 3D builing model of Paton House

\subsection{Baseline model energy simulation results}

The obtained simulation results for the baseline model show that the total annual energy consumption is $304.44 \mathrm{MWh}\left(300.17 \mathrm{kWh} / \mathrm{m}^{2}\right)$, which consists of two primary energy sources natural gas $\left(214.66 \mathrm{kWh} / \mathrm{m}^{2}\right)$ and electricity $\left(85.51 \mathrm{kWh} / \mathrm{m}^{2}\right)$. The specific energy consumption can be divided into four parts, including space heating $\left(206.01 \mathrm{kWh} / \mathrm{m}^{2}\right)$, DHW heating $\left(8.65 \mathrm{kWh} / \mathrm{m}^{2}\right)$, electricity consumption for lighting $\left(31.26 \mathrm{kWh} / \mathrm{m}^{2}\right)$, equipment $\left(50.74 \mathrm{kWh} / \mathrm{m}^{2}\right)$ and pump $(3.51$ $\mathrm{kWh} / \mathrm{m}^{2}$ ). It can be noted that space heating accounts for a significant portion (around $68.4 \%$ ) of the total energy consumption. Fig. 6 illustrates the variations of space heating demand throughout a year, with the highest value $\left(33.90 \mathrm{kWh} / \mathrm{m}^{2}\right)$ in January and the lowest $\left(1.00 \mathrm{kWh} / \mathrm{m}^{2}\right)$ in July. According to the UK Energy Performance Certification (EPC) standard [51], the case study building 
is rated as EPC grade G, which is far below the required building EPC rate (rated E or above). Considering the relatively high energy consumption for space heating, it is urgent to define and implement effective and affordable passive retrofit measures to improve the building envelope thermal performance and reduce the heating demand.

The baseline model of this study is compared with the results of a published research work [52] which evaluated a similar $19^{\text {th }}$-century Victorian house renovation in London, UK, is used to make comparision. With a heating area of $250 \mathrm{~m}^{2}$, the unrefurbished Victorian house has an annual gas consumption of $300 \mathrm{kWh} / \mathrm{m}^{2}$ and electricity consumption of $36 \mathrm{kWh} / \mathrm{m}^{2}$ [52]. This results in a total energy consumption of $336 \mathrm{kWh} / \mathrm{m}^{2}$ annually, which is generally in agreement with the baseline model energy consumption ( $300.17 \mathrm{kWh} / \mathrm{m}^{2}$ annually) presented in this research.

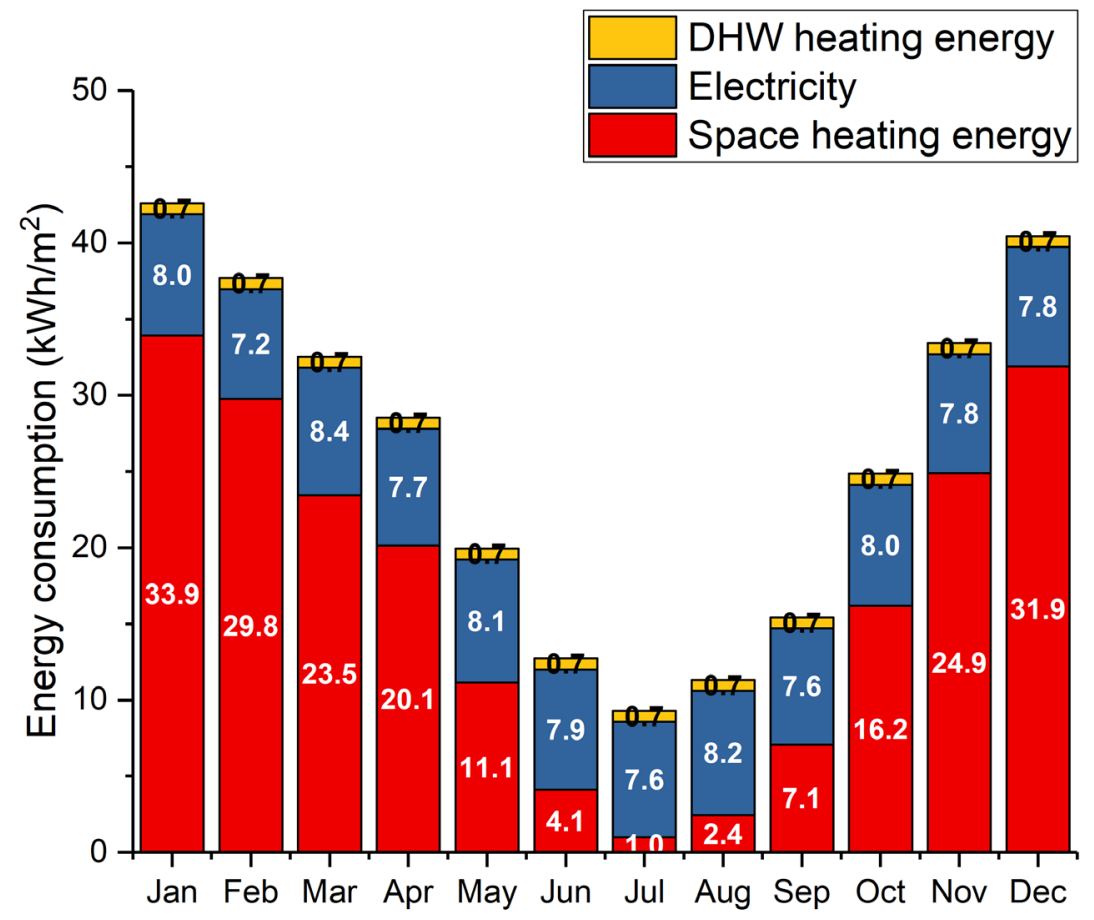

Fig. 6 Space heating demand of the baseline building

\subsection{Selection and classification of passive retrofit measures}

In order to reduce the internal heat losses, the following building retrofit measures focusing on improving the thermal performance of the building envelope will be applied:

1) Five different glazing upgrade measures (G1-G5): double glazing with low-e coating, triple glazing, vacuum glazing, and double vacuum glazing with low-e coating. As shown in Table 3, 
these glazing retrofitting interventions can reduce the $\mathrm{U}$-value between $0.41-1.8 \mathrm{~W} / \mathrm{m}^{2} \mathrm{~K}$ with the initial cost varying between $£ 165 / \mathrm{m}^{2}$ to $£ 570 / \mathrm{m}^{2}$.

2) Three airtightness improvement measures (A1-A3): gypsum insulation, draught proofing, and sealing of the floor/wall joint. The air infiltration rate is reduced between 0.6 to $5.8 \mathrm{ACH}$ under 50Pa between inside and outside, with the initial cost detailed in Table 4 . Phase 4 is a base comparison phase, which indicates that no airtightness improvement measure is considered.

3) In order to maintain the external appearance of this Victorian house, the installation of internal wall thermal insulations (E1-E15) will be considered to improve its thermal performance. This intervention incorporates five different materials, including vacuum insulation panels, silicaaerogel insulation panels, starch-aerogel insulation panels [53], Polyisocyanurate (PIR) insulation panels and mineral wool insulation panels, which are summarised in Table 5. The thermal conductivities of such insulation materials varies from 0.008 to $0.044 \mathrm{~W} / \mathrm{mK}$, respectively, with the initial cost varying from $£ 0.29 / \mathrm{m}^{2}$ to $£ 41.64 / \mathrm{m}^{2}$ for thickness of 1 centimetre.

Although it seems to be an easy option, the installation of insulation layers on top of existing internal walls will potentially lead to different levels of internal space reductions. Without careful design and cost comparisons, this can significantly discourage the homeowners or building investors to undertake building retrofitting. In order to consider this, the potential loss of internal floor space is defined as "internal space volume reduction" $\mathrm{V}_{\mathrm{sr}}$, which is the ratio between the internal space volume reduction and the initial internal space volume for the pre-retrofit scenario.

Therefore, the abovementioned internal wall insulation interventions are respectively categorized into three types, with a thickness of 2, 4 and $8 \mathrm{~cm}$. This leads to 15 different types of internal insulation interventions (E1-E15) with internal space reduction $\mathrm{V}_{\mathrm{sr}}$ ranging from $1.3 \%, 2.6 \%$ to $5.2 \%$.

Table 3 Specifications of the proposed glazing technologies and associated costs

\begin{tabular}{|c|l|l|l|l|l|}
\hline Retrofit & & Double & & Double & Double \\
glazing & Vacuum & glazing & Triple & vacuum & vacuum \\
technologies & glazing & with low- & glazing & glazing & glazing with \\
& & E coating & & & \\
\hline
\end{tabular}




\begin{tabular}{|c|l|l|l|l|l|}
\hline & & & & low-E \\
coating
\end{tabular}

Table 4 Specifications of the proposed airtightness improvement technologies and associated costs

\begin{tabular}{|c|l|l|l|l|}
\hline $\begin{array}{c}\text { Airtightness } \\
\text { improvement } \\
\text { technologies }\end{array}$ & $\begin{array}{l}\text { Gypsum } \\
\text { insulation }\end{array}$ & $\begin{array}{l}\text { Draught } \\
\text { proofing }\end{array}$ & $\begin{array}{l}\text { Sealing of the } \\
\text { floor/wall joint }\end{array}$ & No \\
\hline Retrofit code & $\mathrm{A} 1$ & $\mathrm{~A} 2$ & $\mathrm{~A} 3$ & A4 \\
\hline Infiltration & $\begin{array}{l}0.6 \mathrm{ACH} \\
(50 \mathrm{~Pa})\end{array}$ & $\begin{array}{l}5.8 \mathrm{ACH} \\
(50 \mathrm{~Pa})\end{array}$ & $\begin{array}{l}3.6 \mathrm{ACH} \\
(50 \mathrm{~Pa})\end{array}$ & $\mathrm{NA}$ \\
\hline Cost & $122 £ / \mathrm{m}^{2}[57]$ & $6 £ / \mathrm{m}[58]$ & $9 £ / \mathrm{m}[59]$ & $\mathrm{NA}$ \\
\hline
\end{tabular}

Table 5 Specifications of the proposed internal wall thermal insulation technologies and associated costs

\begin{tabular}{|c|c|c|c|c|c|}
\hline Thermal & & Silica- & Starch- & & \\
insulation & Vacuum & aerogel & aerogel & & \\
technologies & insulation & insulation & insulation & Polyisocyanurate & \\
& panels & panels & panels & (PIR) & Mineral wool \\
\hline Retrofit code & $\mathrm{E} 1, \mathrm{E} 2, \mathrm{E} 3$ & $\mathrm{E} 4, \mathrm{E} 5, \mathrm{E} 6$ & $\mathrm{E} 7, \mathrm{E} 8, \mathrm{E} 9$ & $\mathrm{E} 10, \mathrm{E} 11, \mathrm{E} 12$ & $\mathrm{E} 13, \mathrm{E} 14, \mathrm{E} 15$ \\
\hline
\end{tabular}




\begin{tabular}{|c|l|l|l|l|l|}
\hline $\begin{array}{c}\text { Thermal } \\
\text { conductivity } \\
(\mathrm{W} / \mathrm{mK})\end{array}$ & 0.008 & 0.019 & 0.024 & 0.022 & 0.044 \\
\hline $\begin{array}{c}\text { Thickness } \\
(\mathrm{cm})\end{array}$ & $2,4,8$ & $2,4,8$ & $2,4,8$ & $2,4,8$ & $2,4,8$ \\
\hline $\begin{array}{c}\text { Density } \\
\left(\mathrm{kg} / \mathrm{m}^{3}\right)\end{array}$ & 288 & 200 & 1500 & 45 & 70 \\
\hline $\begin{array}{c}\text { Specific heat } \\
\text { capacity } \\
(\mathrm{J} / \mathrm{kgK})\end{array}$ & 800 & 840 & 2260 & 1800 & 840 \\
\hline $\begin{array}{c}\left.\text { Cost (£/m }{ }^{2}\right) \\
\text { for thickness }\end{array}$ & & $40.15[61]$ & $29.87[62]$ & $1.32[63]$ & $0.29[64]$ \\
\hline \begin{tabular}{c} 
of $1 \mathrm{~cm}$ \\
\hline
\end{tabular} & $41.64[60]$ & 400 & & \\
\hline
\end{tabular}

\subsection{Definition of traditional and advanced retrofit measures}

Traditional retrofit measures are products which have been playing a dominant role in the market, such as polyisocyanurate (PIR) and mineral wool material, draught-proofing, sealing of the floor/wall joint, single and double glazing insulation. The performance characteristics of these traditional retrofit measures are often market-approved with well-established manufacturing chain and design specifications, which leads to relatively low production costs. Advanced retrofit measures are new technologies incorporating novel energy-saving or smart materials such as aerogel, vacuum design material, high airtightness measures. These emergent technologies are associated with higher system performance enhancement. Due to their relatively low market maturity, the current initial costs of such advanced retrofit measures are often higher than the traditional retrofit measures. Therefore, according to relative performance and technology maturity, the proposed passive retrofit measures are further classified into two categories: advanced and traditional measures, which are summarised in Table 6.

Table 6 Classifications of advanced and traditional retrofit measures 


\begin{tabular}{|c|c|c|c|c|c|}
\hline $\begin{array}{l}\text { Retrofit } \\
\text { code }\end{array}$ & Retrofit description & $\begin{array}{l}\text { Advanced or } \\
\text { traditional } \\
\text { measures }\end{array}$ & $\begin{array}{l}\text { Retrofit } \\
\text { code }\end{array}$ & $\begin{array}{l}\text { Retrofit } \\
\text { description }\end{array}$ & $\begin{array}{l}\text { Advanced or } \\
\text { traditional } \\
\text { measures }\end{array}$ \\
\hline G1 & Vacuum glazing & Advanced & $\mathrm{E} 4$ & $\begin{array}{l}\text { Silica-aerogel } \\
8 \mathrm{~cm}\end{array}$ & Advanced \\
\hline G2 & $\begin{array}{l}\text { Double glazing with } \\
\text { low-E coating }\end{array}$ & Traditional & E5 & $\begin{array}{l}\text { Silica-aerogel } \\
4 \mathrm{~cm}\end{array}$ & Advanced \\
\hline G3 & Triple glazing & Traditional & E6 & $\begin{array}{l}\text { Silica-aerogel } \\
2 \mathrm{~cm}\end{array}$ & Advanced \\
\hline G4 & $\begin{array}{l}\text { Double vacuum } \\
\text { glazing }\end{array}$ & Advanced & E7 & $\begin{array}{l}\text { Starch- } \\
\text { aerogel } 8 \mathrm{~cm}\end{array}$ & Advanced \\
\hline G5 & $\begin{array}{l}\text { Double vacuum } \\
\text { glazing with low-E } \\
\text { coating }\end{array}$ & Advanced & E8 & $\begin{array}{l}\text { Starch- } \\
\text { aerogel } 4 \mathrm{~cm}\end{array}$ & Advanced \\
\hline A1 & $\begin{array}{l}\text { Gypsum air } \\
\text { infiltration reduction }\end{array}$ & Advanced & E9 & $\begin{array}{l}\text { Starch- } \\
\text { aerogel } 2 \mathrm{~cm}\end{array}$ & Advanced \\
\hline A2 & Draught proofing & Traditional & E10 & PIR $8 \mathrm{~cm}$ & Traditional \\
\hline A3 & $\begin{array}{l}\text { Sealing of the } \\
\text { floor/wall joint }\end{array}$ & Traditional & E11 & PIR 4cm & Traditional \\
\hline A4 & $\begin{array}{l}\text { No infiltration } \\
\text { improvement }\end{array}$ & Traditional & E12 & PIR 2cm & Traditional \\
\hline E1 & $\begin{array}{l}\text { Vacuum insulation } \\
8 \mathrm{~cm}\end{array}$ & Advanced & E13 & $\begin{array}{l}\text { Mineral wool } \\
8 \mathrm{~cm}\end{array}$ & Traditional \\
\hline E2 & $\begin{array}{l}\text { Vacuum insulation } \\
4 \mathrm{~cm}\end{array}$ & Advanced & E14 & $\begin{array}{l}\text { Mineral wool } \\
4 \mathrm{~cm}\end{array}$ & Traditional \\
\hline E3 & $\begin{array}{l}\text { Vacuum insulation } \\
2 \mathrm{~cm}\end{array}$ & Advanced & E15 & $\begin{array}{l}\text { Mineral wool } \\
2 \mathrm{~cm}\end{array}$ & Traditional \\
\hline
\end{tabular}




\subsection{Retrofit combinations and three defined categories for energy and cost-effective assessments}

After the initial definition and selection, one retrofit measure is selected from the defined three main categories (glazing upgrade, insulation and airtightness improvement), and then integrated to form a comprehensive combination (i.e., GxEyAz). As shown in Table 6, the total number of retrofit measures for glazing upgrade (G1-G5), airtightness improvement (A1-A4) and internal wall insulation (E1-E15) are 5, 4 and 15, respectively. This brings the total possible combinations equal to $5(\mathrm{G}) \times 4(\mathrm{~A}) \times 15(\mathrm{E})=300$ combinations. These combinations are then incorporated with the baseline model and simulated in IES VE programme to obtain the annual primary energy consumption.

As recommended by the European Directive on the energy performance in buildings (EPBD) [5], the "cost-optimal" method will be adopted in this research to analyse the economic benefits including global costs and the payback period of the selected retrofit combinations. For the details of "costoptimal" method, the readers are referred to our previously published paper [20].

According to the Nearly Zero Energy Buildings classifications [42], "Moderate Renovation" is defined as the refurbishment that can achieve energy reduction in the range of $30 \%$ to $60 \%$, which applies typically three to five retrofit measures. "Deep Renovation" is defined as the refurbishment that can achieve energy reduction ranging from $60 \%$ to $90 \%$, with an average total cost of $€ 330 / \mathrm{m}^{2}$ [42] [65] [66]. Therefore, energy-saving and investment costs of all the possible retrofit combinations will be evaluated against these defined renovation levels.

Based on this, the following three optimisation categories are defined. The 300 retrofit combinations are evaluated separately and jointly from the perspectives of energy-saving potentials and costeffectiveness according to the three defined optimisation categories, with the optimal results shown in section 3.3.

1) Maximum energy-saving combination: mainly from energy-saving perspective, the retrofit combinations with maximum energy-saving and the maximum energy reduction.

2) Most cost-effective combination: mainly from cost-effectiveness perspective, the retrofit combinations that are most cost-effective with the minimum payback periods. 
3) Energy-cost combination: from both energy-saving and cost-effectiveness perspective, the retrofit combination with at least $60 \%$ energy reduction and relatively lower payback period, defined as cost-optimal combination under the context of deep renovation.

\section{Results and Discussion}

\subsection{Comparison of advanced and traditional retrofit combinations}

The difference in energy-saving potential, initial investment, and discounted payback periods under the two categories (advanced and traditional retrofit measures) are summarised in Table 7. The breakdown of calculation details including labour cost and capital technology cost, has been included in Appendix 1. Description of economic calculation methods and key parameters are summarized in Appendix 3.

The results show that with the space volume reduction rate $\left(\mathrm{V}_{\mathrm{sr}}\right)$ varying from $\mathrm{V}_{\mathrm{sr}}=5.2 \%(8 \mathrm{~mm}$ insulation thickness), to $\mathrm{V}_{\mathrm{sr}}=2.6 \%$ ( $4 \mathrm{~mm}$ insulation thickness), and $\mathrm{V}_{\mathrm{sr}}=1.3 \%(2 \mathrm{~mm}$ insulation thickness), advanced retrofit combinations have an average energy saving potential of $64.3 \%, 60.8 \%$ and $55.6 \%$, respectively. While, the maximum energy saving potential is presented with $66.8 \%$, $64.7 \%$ and $61.2 \%$, respectively. The traditional retrofit combinations have a slightly lower performance with average and maximum energy saving potential of $48.5 \%$ and $58.2 \%\left(\mathrm{~V}_{\mathrm{sr}}=5.2 \%\right)$, $43.3 \%$ and $53.8 \%\left(\mathrm{~V}_{\mathrm{sr}}=2.6 \%\right), 36.7 \%$ and $47.8 \%\left(\mathrm{~V}_{\mathrm{sr}}=1.3 \%\right)$, respectively.

From the cost-effectiveness point of view, the average initial investment of $£ 788,583\left(\mathrm{~V}_{\mathrm{sr}}=5.2 \%\right)$, $£ 465,055\left(\mathrm{~V}_{\mathrm{sr}}=2.6 \%\right)$, and $£ 303,313\left(\mathrm{~V}_{\mathrm{sr}}=1.3 \%\right)$ of the advanced retrofit combinations are more than tenfold of those for traditional retrofit combinations with $£ 62,088\left(\mathrm{~V}_{\mathrm{sr}}=5.2 \%\right), £ 55,102\left(\mathrm{~V}_{\mathrm{sr}}=\right.$ $2.6 \%)$, and $£ 51,609\left(\mathrm{~V}_{\mathrm{sr}}=1.3 \%\right)$. Consequently, the discounted payback periods for advanced retrofit combinations is as high as averagely 80 years $\left(\mathrm{V}_{\mathrm{sr}}=5.2 \%\right), 52$ years $\left(\mathrm{V}_{\mathrm{sr}}=2.6 \%\right)$, and 43 years $\left(V_{s r}=1.3 \%\right)$, while the traditional retrofit combinations have an average of only 26 years $\left(V_{s r}=5.2 \%\right)$, 40 years $\left(\mathrm{V}_{\mathrm{sr}}=2.6 \%\right)$, and 59 years $\left(\mathrm{V}_{\mathrm{sr}}=1.3 \%\right)$. Therefore, at this stage, the most cost-effective interventions would be traditional retrofit combinations with shorter payback periods. However, it is worth noting that the majority of the selected advanced retrofit measures such as VIP (E1, E2 and E3) and vacuum glazing (G1, G4 and G5) are still at their early commercialization stage. Arguably, 
over the coming years, through the development of technology and advanced manufacturing techniques, the investment costs for these advanced retrofit combinations could be substantially reduced. This can potentially lead to drastic reductions in costs and payback period, for the selected advanced retrofit combinations.

Therefore, as $\mathrm{V}_{\mathrm{sr}}$ decreasing from $5.2 \%$ to $1.3 \%$, the energy and cost-effectiveness of the advanced retrofit combinations is increasing, and higher than the traditional retrofit combinations with conditions of only $1.3 \%$ space volume reduction. Under the space reduction rate of $1.3 \%$, the advanced retrofit combinations are more effective than the traditional retrofit combinations with around $27.1 \%$ reduction in the payback period.

Table 7 Energy and economic assessment for advanced and traditional retrofit combinations

\begin{tabular}{|c|c|c|c|c|c|c|c|c|c|}
\hline \multicolumn{5}{|c|}{ Advanced Retrofit Combinations } & \multicolumn{5}{|c|}{ Traditional Retrofit Combinations } \\
\hline $\mathrm{V}_{\mathrm{sr}}$ & $\begin{array}{l}\text { Retrofit } \\
\text { combinati } \\
\text { on code }\end{array}$ & $\begin{array}{l}\text { Energy- } \\
\text { saving } \\
\text { potential }\end{array}$ & $\begin{array}{c}\text { Initial } \\
\text { investment } \\
\text { cost }\end{array}$ & $\begin{array}{c}\text { Payback } \\
\text { periods } \\
\text { (years) }\end{array}$ & $\mathrm{V}_{\mathrm{sr}}$ & $\begin{array}{c}\text { Retrofit } \\
\text { combinatio } \\
\mathrm{n} \text { code }\end{array}$ & $\begin{array}{l}\text { Energy- } \\
\text { saving } \\
\text { potential }\end{array}$ & $\begin{array}{c}\text { Initial } \\
\text { investmen } \\
\text { t cost }\end{array}$ & $\begin{array}{c}\text { Payback } \\
\text { period } \\
\text { (years) }\end{array}$ \\
\hline \multirow{12}{*}{$5.2 \%$} & G1A1E1 & $65.7 \%$ & $£ 831,147$ & 80 & \multirow{12}{*}{$\begin{array}{c}5.2 \\
\%\end{array}$} & G2A2E10 & $53.2 \%$ & $£ 66,296$ & 9 \\
\hline & G4A1E1 & $66.3 \%$ & $£ 873,612$ & 83 & & G2A3E10 & $56.4 \%$ & $£ 74,774$ & 9 \\
\hline & G5A1E1 & $66.8 \%$ & $£ 891,492$ & 83 & & G2A4E10 & $39.6 \%$ & $£ 54,236$ & 33 \\
\hline & G1A1E4 & $63.0 \%$ & $£ 805,246$ & 86 & & G3A2E10 & $55.1 \%$ & $£ 78,216$ & 10 \\
\hline & G4A1E4 & $63.6 \%$ & $£ 847,711$ & 89 & & G3A3E10 & $58.2 \%$ & $£ 86,694$ & 10 \\
\hline & G5A1E4 & $64.1 \%$ & $£ 865,591$ & 89 & & G3A4E10 & $41.4 \%$ & $£ 66,156$ & 29 \\
\hline & G1A1E7 & $62.6 \%$ & $£ 626,544$ & 66 & & G2A2E13 & $48.9 \%$ & $£ 48,348$ & 9 \\
\hline & G4A1E7 & $63.2 \%$ & $£ 669,009$ & 70 & & G2A3E13 & $52.1 \%$ & $£ 56,826$ & 9 \\
\hline & G5A1E7 & $63.7 \%$ & $£ 686,889$ & 70 & & G2A4E13 & $35.3 \%$ & $£ 36,288$ & 100 \\
\hline & & & & & & G3A2E13 & $50.8 \%$ & $£ 60,268$ & 10 \\
\hline & & & & & & G3A3E13 & $53.9 \%$ & $£ 68,746$ & 10 \\
\hline & & & & & & G3A4E13 & $37.1 \%$ & $£ 48,208$ & 72 \\
\hline \multirow{3}{*}{$2.6 \%$} & G1A1E2 & $63.6 \%$ & $£ 469,224$ & 46 & \multirow{3}{*}{$\begin{array}{c}2.6 \\
\%\end{array}$} & G2A2E11 & $48.9 \%$ & $£ 54,823$ & 10 \\
\hline & G4A1E2 & $64.3 \%$ & $£ 511,689$ & 50 & & G2A3E11 & $52.0 \%$ & $£ 63,301$ & 10 \\
\hline & G5A1E2 & $64.7 \%$ & $£ 529,569$ & 51 & & G2A4E11 & $35.3 \%$ & $£ 42,763$ & 100 \\
\hline
\end{tabular}




\begin{tabular}{|c|c|c|c|c|c|c|c|c|c|}
\hline & G1A1E5 & $59.0 \%$ & $£ 456,209$ & 55 & & G3A2E11 & $50.7 \%$ & $£ 66,743$ & 11 \\
\hline & G4A1E5 & $59.6 \%$ & $£ 498,674$ & 59 & & G3A3E11 & $53.8 \%$ & $£ 75,221$ & 10 \\
\hline & G5A1E5 & $60.1 \%$ & $£ 516,554$ & 60 & & G3A4E11 & $37.1 \%$ & $£ 54,683$ & 84 \\
\hline & G1A1E8 & $58.1 \%$ & $£ 366,923$ & 45 & & G2A2E14 & $42.8 \%$ & $£ 45,849$ & 16 \\
\hline & G4A1E8 & $58.7 \%$ & $£ 409,388$ & 49 & & G2A3E14 & $46.0 \%$ & $£ 54,327$ & 13 \\
\hline & G5A1E8 & $59.2 \%$ & $£ 427,268$ & 51 & & G2A4E14 & $29.2 \%$ & $£ 33,789$ & 100 \\
\hline & & & & & & G3A2E14 & $44.7 \%$ & $£ 57,769$ & 16 \\
\hline & & & & & & G3A3E14 & $47.8 \%$ & $£ 66,247$ & 14 \\
\hline & & & & & & G3A4E14 & $31.0 \%$ & $£ 45,709$ & 100 \\
\hline & G1A1E3 & $60.1 \%$ & $£ 288,263$ & 32 & & G2A2E12 & $42.8 \%$ & $£ 49,087$ & 17 \\
\hline & G4A1E3 & $60.7 \%$ & $£ 330,728$ & 36 & & G2A3E12 & $46.0 \%$ & $£ 57,565$ & 14 \\
\hline & G5A1E3 & $61.2 \%$ & $£ 348,608$ & 37 & & G2A4E12 & $29.2 \%$ & $£ 37,027$ & 100 \\
\hline & G1A1E6 & $53.2 \%$ & $£ 281,755$ & 44 & & G3A2E12 & $44.7 \%$ & $£ 61,007$ & 17 \\
\hline & G4A1E6 & $53.9 \%$ & $£ 324,220$ & 49 & & G3A3E12 & $47.8 \%$ & $£ 69,485$ & 15 \\
\hline & G5A1E6 & $54.3 \%$ & $£ 342,100$ & 51 & 1.3 & G3A4E12 & $31.0 \%$ & $£ 48,947$ & 100 \\
\hline & G1A1E9 & $51.8 \%$ & $£ 237,112$ & 40 & $\%$ & G2A2E15 & $35.7 \%$ & $£ 44,599$ & 100 \\
\hline & G4A1E9 & $52.4 \%$ & $£ 279,577$ & 46 & & G2A3E15 & $38.9 \%$ & $£ 53,077$ & 42 \\
\hline & G5A1E9 & $52.9 \%$ & $£ 297,457$ & 48 & & G2A4E15 & $22.1 \%$ & $£ 32,539$ & 100 \\
\hline & & & & & & G3A2E15 & $37.6 \%$ & $£ 56,519$ & 74 \\
\hline & & & & & & G3A3E15 & $40.7 \%$ & $£ 64,997$ & 33 \\
\hline & & & & & & G3A4E15 & $23.9 \%$ & $£ 44,459$ & 100 \\
\hline
\end{tabular}

When considering the internal wall insulation, it is vital to avoid significant internal space reduction in order to maintain a well-balanced internal space after retrofit. Taking this into consideration, advanced retrofit measures with $1.3 \%$ of space volume reduction ( $2 \mathrm{~mm}$ thickness) will be the most attractive option from the perspectives of energy and cost-effectiveness.

To further understand the energy performance and the cost-effectiveness between the advanced and traditional retrofit combinations, discounted payback periods and specific cost payback periods are analysed. Discounted payback periods (DPP) is defined as the cumulative discounted net present values to base year, which is developed and applied with a specific discounting cash flow 
approach to evaluate an investment in renovation to improve building quality, thus increasing energy efficiency [67]. Specific cost payback periods (SCPP) is defined as the discounted payback periods (DPP) divided by the initial investment, with the unit of years/k£, which is developed in this research based on the concept of discounted cash flow. The criteria will indicate the specific payback periods under a unit investment capacity, and the economic performance of investment payback ability.

As shown in Fig 8 (a), only a few advanced retrofit combinations with $1.3 \%, 2.6 \%$ and $5.2 \%$ of space volume reduction can achieve the threshold of $60 \%$ energy reduction rate compared with the baseline scenario. However, for the majority of the traditional retrofit combinations, the achievable energy reduction rate can hardly go beyond $60 \%$ with constant payback periods of approximately 10 years. Besides, the specific cost payback periods describe the cost-effectiveness of the initial investment, namely, the payback periods of each $£ 1000$. As shown in Fig. 8 (b), with an increasing energy reduction rate, the specific cost payback period keeps descending, regardless of whether it is a traditional or an advanced retrofit combination.

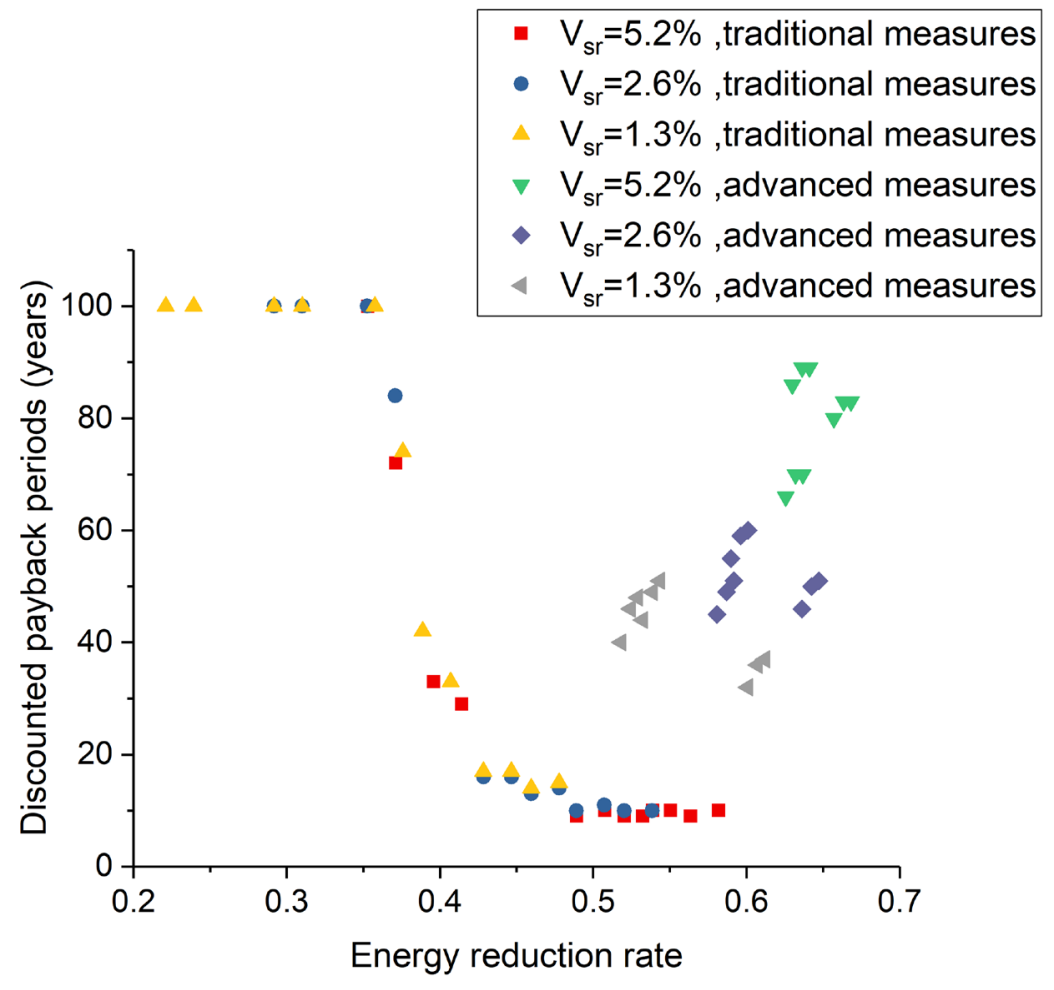

(a) Discounted payback time 


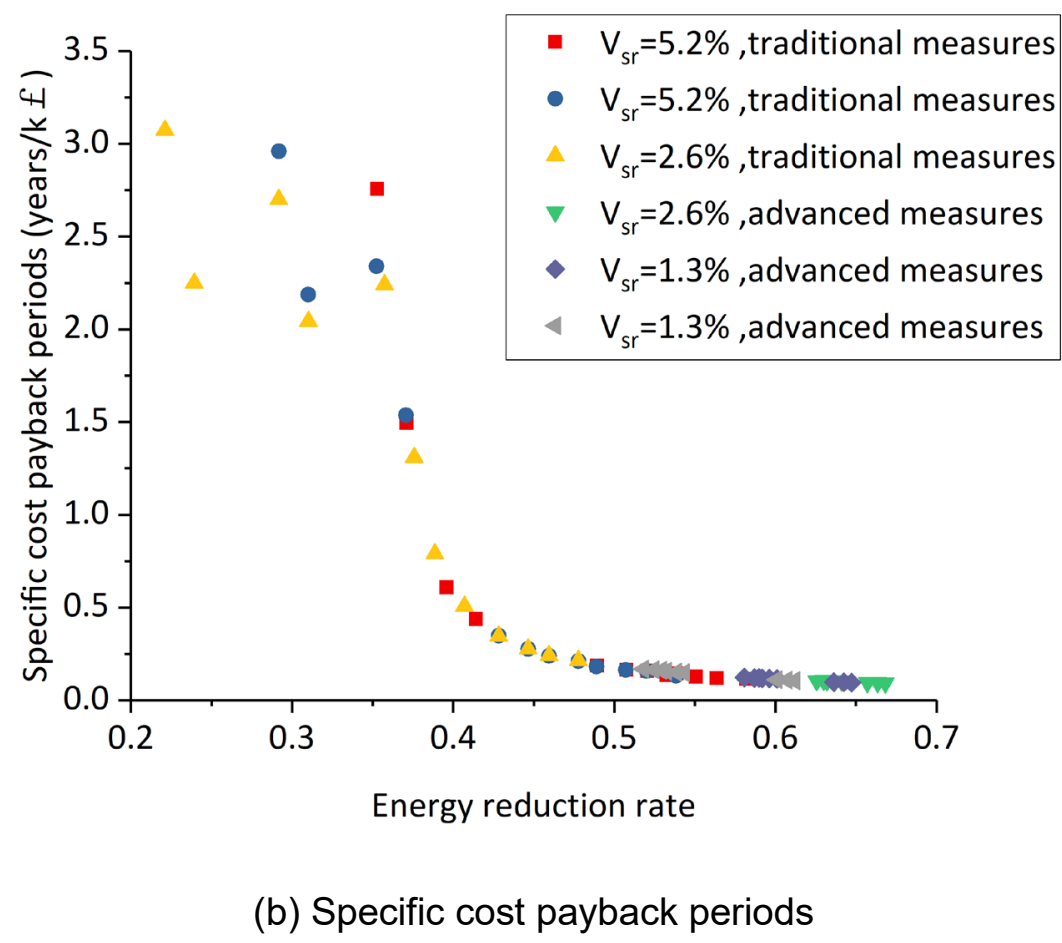

Fig. 8 Performance in terms of the cost-effectiveness between the advanced and traditional retrofit combinations

\subsection{Comparison of all the retrofit combinations under three defined categories (maximum energy saving, most cost-effective and energy-cost)}

This section will aim to compare the energy performance and cost benefits for the comprehensive combinations according to the categories outlined in section 2.4 .

The variations of discounted payback periods and specific costs under a range of energy reduction rates are shown in Fig. 9(a) and Fig. 9(b) for three different space reduction rates. Fig. 9(c) is a 3dimensional presentation with integration of Fig. 9(a) and Fig. 9(b), which collects all the comprehensive retrofit combinations. The breakdown of calculation results for these comprehensive combinations is included in Appendix 2. The concept of the specific cost is used to compare the effectiveness of retrofit cost in different retrofit combinations under the same unit of floor area. With a space volume reduction of $5.2 \%$, the maximum energy saving occurred in retrofit intervention G5A1E1, with $66.8 \%$ of primary energy reduction to $99.61 \mathrm{kWh} / \mathrm{m}^{2}$ of annual energy consumption. This intervention is the combination of double vacuum glazing with low-E coating, gypsum air infiltration reduction, and $8 \mathrm{~mm}$ vacuum insulation panels, with an initial investment of $£ 878.99 / \mathrm{m}^{2}$. The corresponding discounted payback period of combination G5A1E1 is 83 years, which at this 
case, is too high to be accepted by home owners or investors. Therefore, G5A1E1 could not be considered as the most cost-effective combination. Arguably, this intervention has great potential to be supplemented with renewable energy measures (e.g. solar PV), which can generate electricity onsite according to users' demands, leading to significantly reduced energy bills and associated shorted payback period. However, this is out of the scope of the research presented in this paper, which mainly focuses on the passive measures to be applied to historical building renovations. Therefore, the maximum energy saving within payback periods of 30 years is G5A1E10, with energy saving potential of $63.3 \%$ and initial investment of $£ 207.92 / \mathrm{m}^{2}$. For $\mathrm{V}_{\mathrm{sr}}=5.2 \%$, the most cost-effective combination is G1A3E13 (vacuum glazing, sealing of the floor/wall joint, and 8cmm thickness of mineral wool), which results in $53.7 \%$ energy reduction compared with the baseline scenario. The discounted payback period is 7 years, with the initial investment of only $£ 49.42 / \mathrm{m}^{2}$. When targeting at more than $60 \%$ of energy reduction rate with the minimum payback period, the most energyeffective combination is $\mathrm{G} 1 \mathrm{~A} 1 \mathrm{E} 10$, with vacuum glazing, gypsum air infiltration reduction, and $8 \mathrm{~cm}$ thickness of PIR panels, which has an energy-saving potential of $62.2 \%$ with annual energy consumption of $113.50 \mathrm{kWh} / \mathrm{m}^{2}$. The discounted payback period is reasonable of 13 years with and initial investment of $£ 128.42 / \mathrm{m}^{2}$.

For space volume reduction rate of $2.6 \%$, the maximum energy saving combination is G5A1E2, with $64.7 \%$ of primary energy reduction to $105.87 \mathrm{kWh} / \mathrm{m}^{2}$ of annual energy consumption. This intervention is combined with double vacuum glazing with low-E coating, gypsum air infiltration reduction, and $4 \mathrm{~mm}$ vacuum insulation panels, with an initial investment of $£ 522.14 / \mathrm{m}^{2}$ and the payback periods of 51 years, which is higher than 30 years. Therefore, the maximum energy saving combination within 30 years' payback periods occurred in G5A1E11, which has energy saving potential of $59.0 \%$ and initial investment of $£ 110.16 / \mathrm{m}^{2}$. The most cost-effective combination under $\mathrm{V}_{\mathrm{sr}}$ of $2.6 \%$ is G1A3E11 (vacuum glazing, sealing of the floor/wall joint, and $4 \mathrm{cmm}$ thickness of PIR panels), which results in the energy reduction rate of $53.7 \%$ to $139.06 \mathrm{kWh} / \mathrm{m}^{2}$. The discounted payback period is 8 years, with the initial investment of only $£ 55.80 / \mathrm{m}^{2}$. When targeting at higher energy reduction rate with the minimum payback period, the most favourable energy-cost combination is G1A1E11, with an energy-saving potential of $57.9 \%$ (maximum energy saving 
potential is less than $60 \%$ with space volume reduction rate of $2.6 \%$ ), discounted payback periods of 14 years and an initial investment of $£ 117.11 / \mathrm{m}^{2}$. It is worthwhile pointing out that this intervention is the main combinations of advanced technologies (double vacuum glazing with low-E coating G5, gypsum air infiltration reduction $\mathrm{A} 1$, and $4 \mathrm{~cm}$ thickness of PIR E11). This means that in order to achieve adequate energy saving potential with minimum investment, it would be preferable to choose the advanced technologies, rather than relying on the traditional retrofit combinations.

When applying an additional layer of internal insulation for building retrofit, householders would prefer to have a minimum alteration to their internal usable space. Taking this into account, the space volume reduction rate of $1.3 \%$ with the minimum thickness of the insulation layer $(2 \mathrm{~mm})$ will be the ideal option. For $\mathrm{V}_{\mathrm{sr}}=1.3 \%$, the maximum energy saving combination is $\mathrm{G} 1 \mathrm{~A} 3 \mathrm{E} 3$, with $55.9 \%$ of primary energy reduction to $132.38 \mathrm{kWh} / \mathrm{m}^{2}$ of annual energy consumption. By applying vacuum glazing, sealing of the floor/wall joint and $2 \mathrm{~mm}$ vacuum insulation panels in this combination, the initial investment cost is $£ 122.91 / \mathrm{m}^{2}$, with the payback period of 19 years. The most cost-effective combination for $V_{\mathrm{sr}}=1.3 \%$ is $\mathrm{G} 1 \mathrm{~A} 3 \mathrm{E} 12$ (combinations of vacuum glazing, sealing of the floor/wall joint, and $2 \mathrm{cmm}$ thickness of PIR panels), which results in the energy reduction rate of $47.6 \%$, discounted payback period of 11 years and initial investment of only $£ 50.15 / \mathrm{m}^{2}$. However, when considering a higher energy reduction rate, the most energy-effective combination is G1A1E12, which has an energy-saving potential of $51.8 \%$ with an annual energy consumption of 144.71 $\mathrm{kWh} / \mathrm{m}^{2}$. The discounted payback period is increased to 18 years, with an initial investment of $£ 111.45 / \mathrm{m}^{2}$. This intervention is the combination of all advanced technologies, including vacuum glazing $\mathrm{G} 1$, gypsum air infiltration reduction $\mathrm{A} 1$, and $2 \mathrm{~cm}$ thickness of PIR E3. Therefore, similar to the previous scenario, for $\mathrm{V}_{\mathrm{sr}}=1.3 \%$, only by combining with the advanced retrofit technologies, can it achieve the target of higher energy reduction with minimum payback period.

Table 8 summarises the optimised results with the defined "maximum energy", "most cost-effective", and "energy-cost combinations" under the space reduction rate of $1.3 \%, 2.6 \%$ and $5.2 \%$. The energy-saving potential and the cost-optimal analysis for all the possible combinations with at least $60 \%$ energy reduction is illustrated in Fig. 9 (d). It can be found that, for these combinations, the energy-saving potential and investment costs are in the range from $60 \%$ to $67 \%$ and $£ 128.42 / \mathrm{m}^{2}$ to 
$£ 878.99 / \mathrm{m}^{2}$, with the discounted payback period from 13 to 90 years. If considering the lowest space reduction rate of $1.3 \%$, there are in total four combinations (G1A1E3, G3A1E3, G4A1E3 and G5A1E3) that can fit into "the maximum energy" and "most cost-effective" categories. This indicates that two of the selected retrofitting measures-gypsum air infiltration reduction (A1) and $2 \mathrm{cmm}$ vacuum insulation panels (E3) are very crucial to achieve the target of $60 \%$ annual energy reduction ("Deep Renovation" as defined by BPIE [42]). Among these four retrofit combinations, the energy reduction rate and initial investment vary from $60.1 \%$ to $61.2 \%$ and $£ 202.66 / \mathrm{m}^{2}$ to $£ 284.22 / \mathrm{m}^{2}$ respectively, which results in the discounted payback periods reasonably between 32 to 37 years. Moreover, the optimized combinations with maximum payback periods of 30 year with EPC grade and SAP score are summarised in Table 8, with EPC scale varied between D and E, and SAP score varied between 44 and 54 . It can be found that for the post-retrofit scenario, without introducing any other active retrofit measures, the implementation of a range of passive retrofit combinations can achieve the minimum grade $\mathrm{E}$ according to UK EPC guidance.

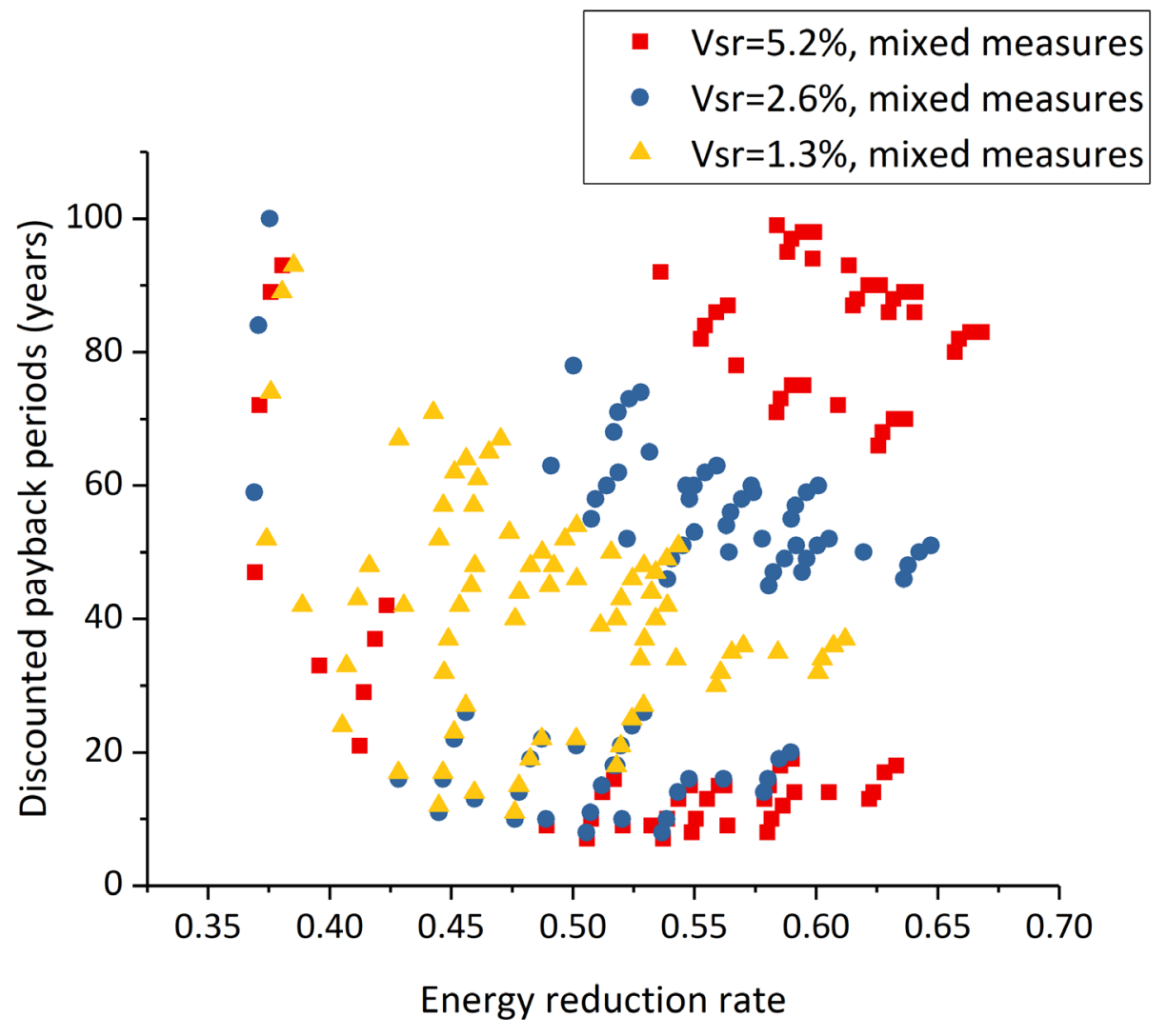

(a) Discounted payback periods under increased energy reduction rate 


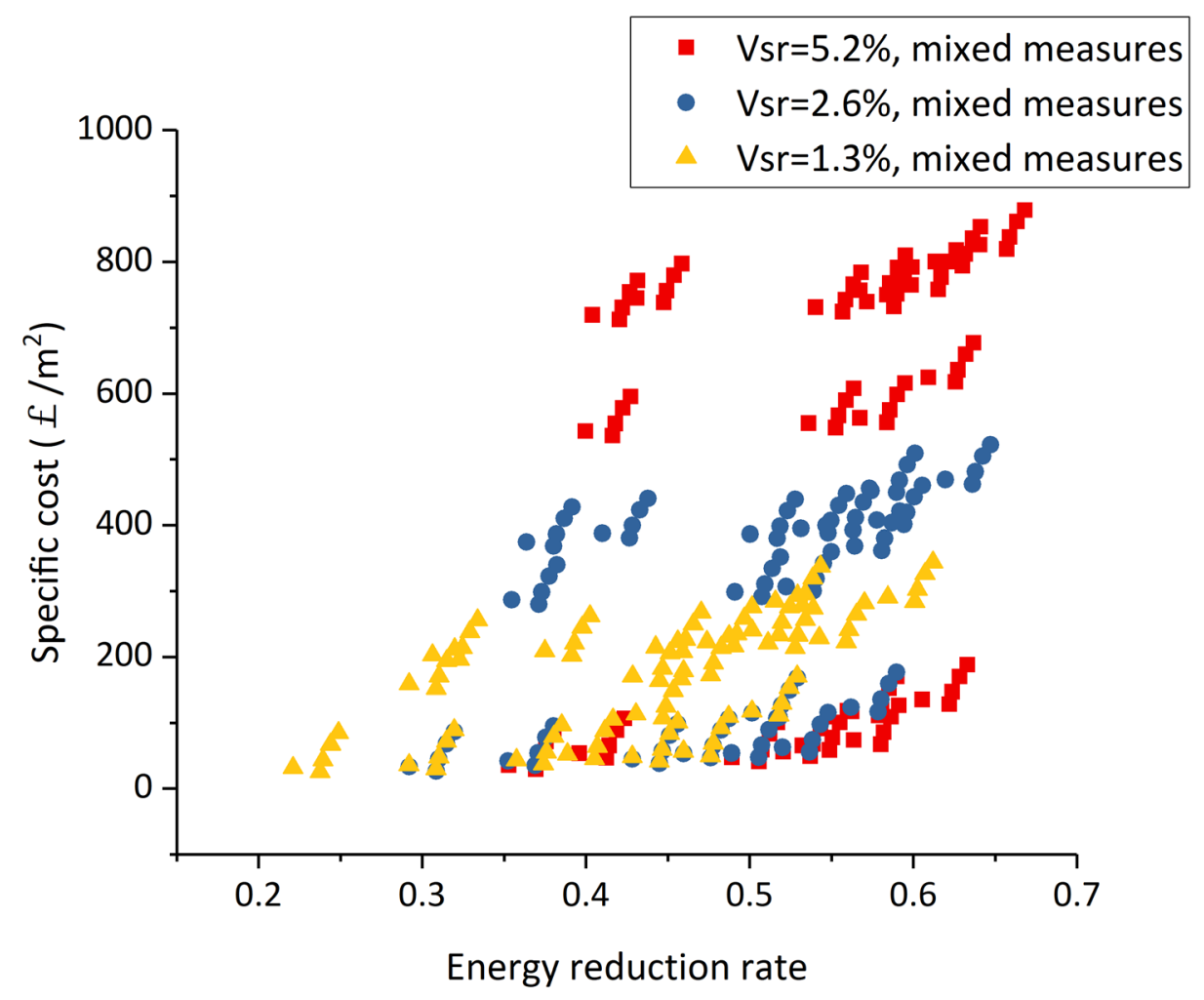

(b) Specific cost under increased energy reduction rate

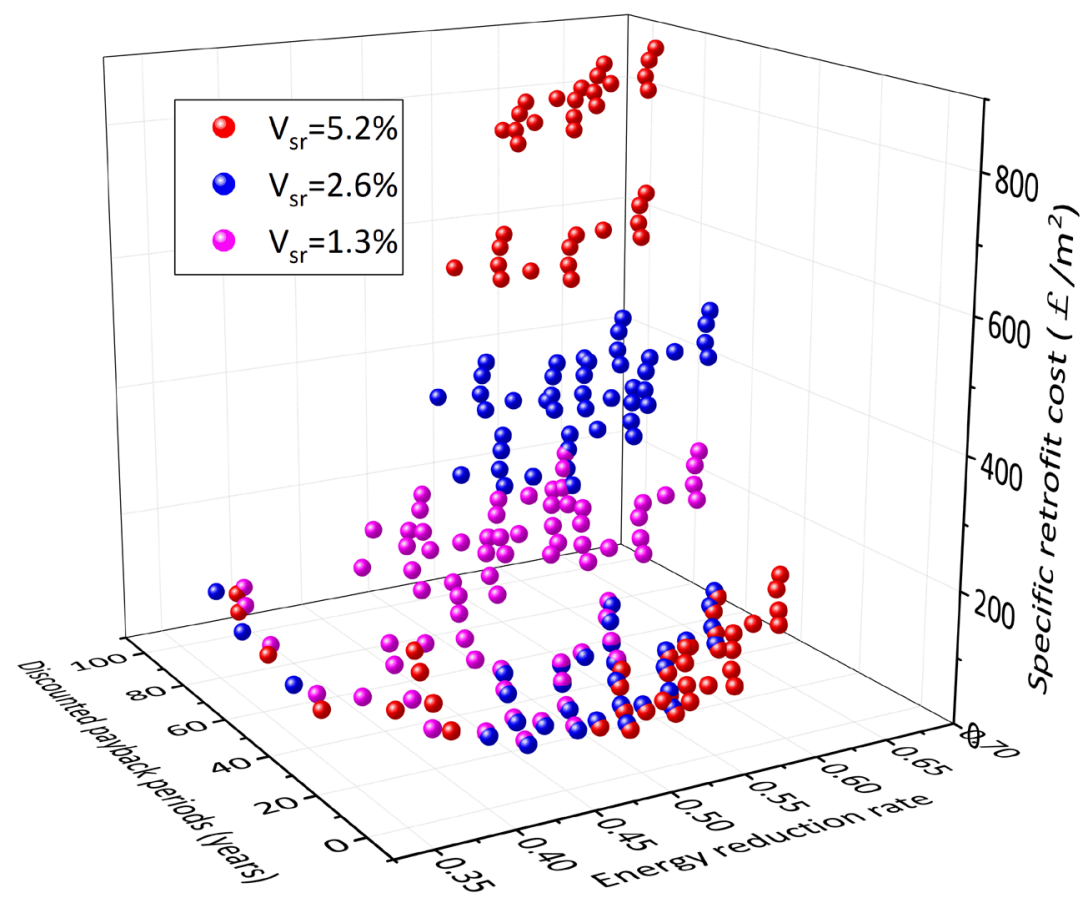

(c) Energy and cost analysis for all retrofit combinations 


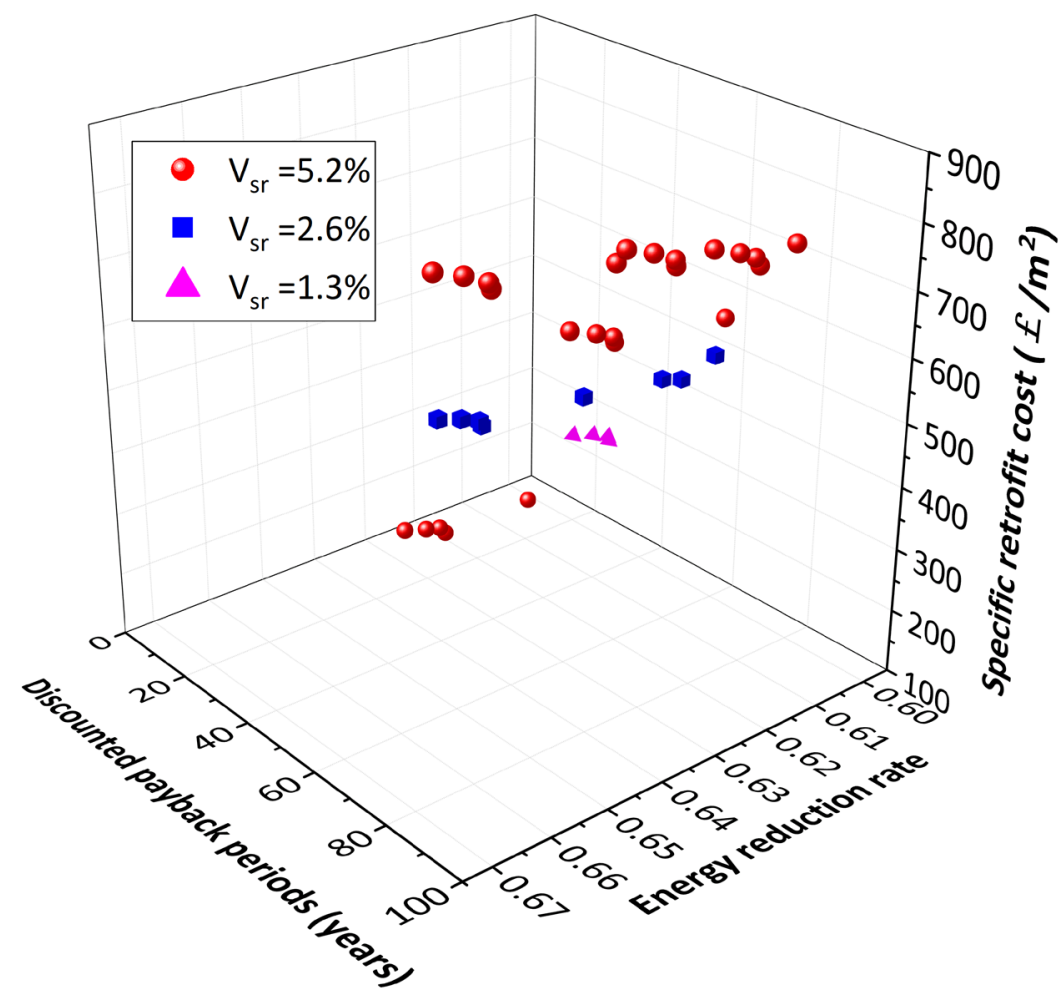

(d) Energy and cost analysis for the combinations with over $60 \%$ energy reduction

Fig. 9 Results of all mixed passive retrofit combinations

Table 8 Comparison of maximum energy, cost-effective and energy-effective combinations

\begin{tabular}{|c|c|c|c|c|}
\hline $\begin{array}{l}\text { Space } \\
\text { reduction } \\
\text { rate } \mathrm{V}_{\mathrm{sr}}\end{array}$ & Specifications & $\begin{array}{c}\text { Maximum } \\
\text { energy } \\
\text { saving } \\
\text { combinations }\end{array}$ & $\begin{array}{l}\text { Most cost- } \\
\text { effective } \\
\text { combinations }\end{array}$ & $\begin{array}{l}\text { Energy-cost } \\
\text { combinations }\end{array}$ \\
\hline \multirow{4}{*}{$5.2 \%$} & Combination code & G5A1E10 & G1A3E13 & G1A1E10 \\
\hline & $\begin{array}{l}\text { Energy saving } \\
\text { potential }\end{array}$ & $63.3 \%$ & $53.7 \%$ & $62.2 \%$ \\
\hline & $\begin{array}{l}\text { Payback periods } \\
\text { (years) }\end{array}$ & 24 & 7 & 13 \\
\hline & $\begin{array}{l}\text { Initial investment } \\
\left(£ / \mathrm{m}^{2}\right)\end{array}$ & 207.92 & 49.42 & 128.42 \\
\hline
\end{tabular}




\begin{tabular}{|c|c|c|c|c|}
\hline & $\begin{array}{l}\text { Annual energy } \\
\text { consumption } \\
\left(\mathrm{kWh} / \mathrm{m}^{2}\right)\end{array}$ & 110.16 & 138.97 & 113.50 \\
\hline & EPC grade/SAP score & $E / 54$ & $E / 48$ & $\mathrm{E} / 54$ \\
\hline \multirow{6}{*}{$2.6 \%$} & Combination code & G5A1E11 & G1A3E11 & G1A1E11 \\
\hline & $\begin{array}{l}\text { Energy saving } \\
\text { potential }\end{array}$ & $59.0 \%$ & $53.7 \%$ & $57.9 \%$ \\
\hline & $\begin{array}{l}\text { Payback periods } \\
\text { (years) }\end{array}$ & 20 & 8 & 14 \\
\hline & $\begin{array}{l}\text { Initial investment } \\
\left(£ / \mathrm{m}^{2}\right)\end{array}$ & 176.61 & 55.80 & 117.11 \\
\hline & $\begin{array}{l}\text { Annual energy } \\
\text { consumption } \\
\left(\mathrm{kWh} / \mathrm{m}^{2}\right)\end{array}$ & 123.16 & 139.06 & 126.50 \\
\hline & EPC grade/SAP score & $E / 52$ & $E / 48$ & $\mathrm{E} / 51$ \\
\hline \multirow{6}{*}{$1.3 \%$} & Combination code & G1A3E3 & G1A3E12 & G1A1E12 \\
\hline & $\begin{array}{l}\text { Energy saving } \\
\text { potential }\end{array}$ & $55.9 \%$ & $47.6 \%$ & $51.8 \%$ \\
\hline & $\begin{array}{l}\text { Payback periods } \\
\text { (years) }\end{array}$ & 19 & 11 & 18 \\
\hline & $\begin{array}{l}\text { Initial investment } \\
\left(£ / \mathrm{m}^{2}\right)\end{array}$ & 122.91 & 50.15 & 111.45 \\
\hline & $\begin{array}{l}\text { Annual energy } \\
\text { consumption } \\
\left(\mathrm{kWh} / \mathrm{m}^{2}\right)\end{array}$ & 132.38 & 157.27 & 144.71 \\
\hline & EPC grade/SAP score & $E / 49$ & $E / 44$ & $\mathrm{E} / 47$ \\
\hline
\end{tabular}




\subsection{Post-retrofit comfort level assessment}

This section assesses the comfort level of three selected passive retrofit combinations under the lowest space volume reduction rate of 1.3\%: G5A1E3 and G1A1E3 represent the interventions with all the advanced retrofit technologies. At the same time, G1A3E12 refers to the mixed combinations between advanced and traditional retrofit technologies. Several important factors, including indoor mean air temperature, indoor air temperature and insulated heating/cooling degree days are selected to evaluate the comfort performance of the ground floor, first floor and attic floor. Insulated heating degree days (IHDDs) and insulated cooling degree days (ICDDs) are considered as indicators for the actual energy consumption of the individual building, which has been applied widely in Heating, Ventilating and Air-Conditioning (HVAC) industries [68]. Based on the fact of previous research of heating degree days and cooling degree days with reference to [69], this paper proposed a developed concept of insulated heating/cooling degree days (IHDDs/ICDDs), which is calculated by the sum of the temperature difference between $T_{r}$ (room temperature) and $T_{a m b}$ (ambient temperature), to reflect the total heating and cooling demand under the conditions of fabric insulation materials. The details of calculation methods are shown in Equation (1) and (2).

$$
\begin{aligned}
& \text { IHDDs }=\sum_{t=1}^{n}\left(\theta_{s t d, h}-T_{r}(t)\right) \\
& \text { ICDDs }=\sum_{t=1}^{n}\left(T_{r}(t)-\theta_{s t d, c}\right)
\end{aligned}
$$

where IHDDs or ICDDs $\left({ }^{\circ} \mathrm{C} \cdot\right.$ days $)$ is the heating or cooling degree days under fabric insulated conditions for a defined winter or summer indoor heating comfort reference temperature $\theta_{\text {std }, h}$ or $\theta_{s t d, c} . T_{r}(t)$ is the daily indoor average temperature without heating/cooling system.

The comfort performance for the selected retrofit combination is varied at different floors of this Victorian house throughout the year. Fig.10 indicates that the indoor mean air temperature from ground floor to attic floor for the combination of G1A3E3 (with maximum energy saving potential in the space reduction rate of $1.3 \%$ ) in comparison with the baseline. For the baseline, the indoor maximum and minimum temperatures of the ground floor, first floor and attic floor are in the range of $4.5^{\circ} \mathrm{C}-26.3^{\circ} \mathrm{C}, 2.2^{\circ} \mathrm{C}-26.3^{\circ} \mathrm{C}$ and $0^{\circ} \mathrm{C}-29.2^{\circ} \mathrm{C}$, respectively. From June to September, in the baseline, the temperature of the ground floor, first floor and attic floor are in the range of $17^{\circ} \mathrm{C}-26.3^{\circ} \mathrm{C}$, 
$17.5^{\circ} \mathrm{C}-26.3^{\circ} \mathrm{C}$ and $15^{\circ} \mathrm{C}-29.2^{\circ} \mathrm{C}$, respectively. After the retrofit, the monthly winter temperature for G1A3E3 is fluctuating in a similar pattern of the baseline scenario, while the summer temperature remains relatively stable. The indoor maximum and minimum temperatures of the ground floor, first floor and attic floor are in the range of $8^{\circ} \mathrm{C}-28.8^{\circ} \mathrm{C}, 6.8^{\circ} \mathrm{C}-29.7^{\circ} \mathrm{C}$ and $5.1^{\circ} \mathrm{C}-30.7^{\circ} \mathrm{C}$ respectively, which are on average $4.4^{\circ} \mathrm{C}$ higher than baseline scenario. The monthly temperature at each floor in the summer period also slightly increases. It should be noted that after applying the intervention of G1A3E3, at the end of August, the summer overheating issue could be observed. It was $0.8^{\circ} \mathrm{C}$, $1.7^{\circ} \mathrm{C}$ and $2.7^{\circ} \mathrm{C}$ higher than the assumed standard summer temperature $\left(28^{\circ} \mathrm{C}\right)$ respectively in the ground floor, the first floor and the attic.

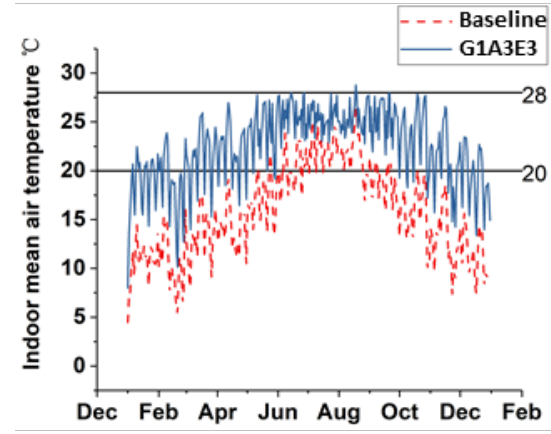

(a) Ground floor

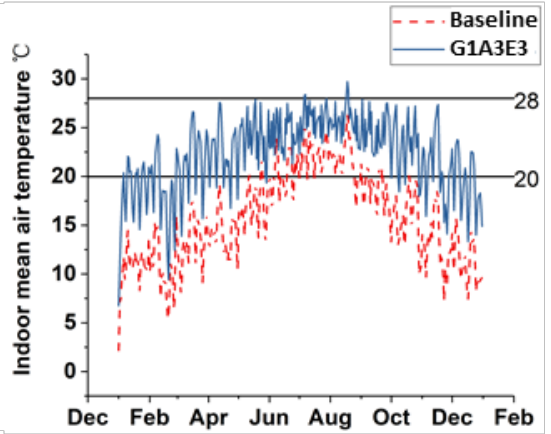

(b) First f loor

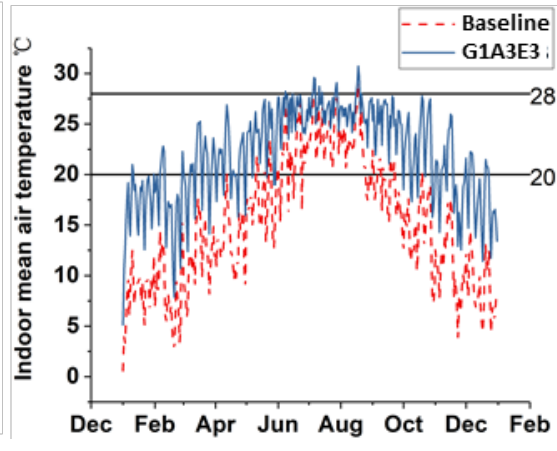

(c) Attic floor

Fig.10 Indoor mean air temperature for retrofit combination G1A3E3

Fig. 11 indicates indoor mean air temperature for combination G1A1E12 from ground floor to attic floor. With $47.6 \%$ energy reduction after the retrofit, the indoor maximum and minimum temperatures of the ground floor, first floor and attic floor are in the range of $7.5^{\circ} \mathrm{C}-28.5^{\circ} \mathrm{C}, 6.4^{\circ} \mathrm{C} 29.5^{\circ} \mathrm{C}$ and $4.9^{\circ} \mathrm{C}$ $30.6^{\circ} \mathrm{C}$, respectively. The average temperature range for the post-retrofit scenario is between $6.3^{\circ} \mathrm{C}$ $29.5^{\circ} \mathrm{C}$, which is on average $4.1^{\circ} \mathrm{C}$ higher than the baseline scenario. Similar to the previous case, a slightly summer overheating issue could be observed for this intervention. From June to September, the temperature ranges of the ground floor, first floor and attic floor are $20^{\circ} \mathrm{C}-28.5^{\circ} \mathrm{C}$, $19^{\circ} \mathrm{C}-29.5^{\circ} \mathrm{C}$ and $18.5^{\circ} \mathrm{C}-30.6^{\circ} \mathrm{C}$, respectively, which is around $0.5^{\circ} \mathrm{C}, 1.5^{\circ} \mathrm{C}$ and $2.6^{\circ} \mathrm{C}$ higher than the assumed standard summer temperature $\left(28^{\circ} \mathrm{C}\right)$ respectively in the ground floor, the first floor and the attic. 


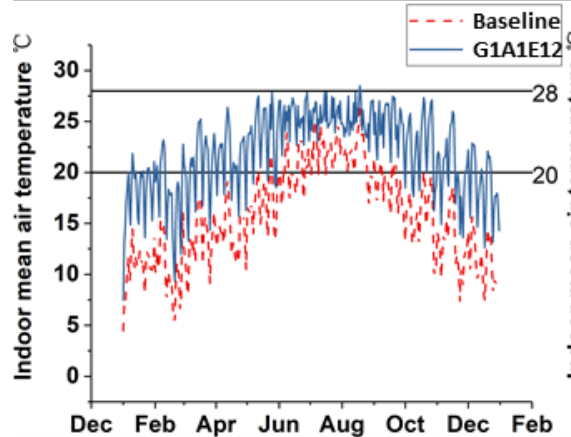

(a) Ground floor

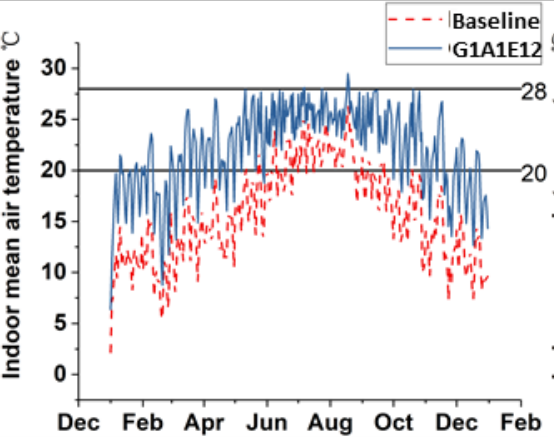

(b) First floor

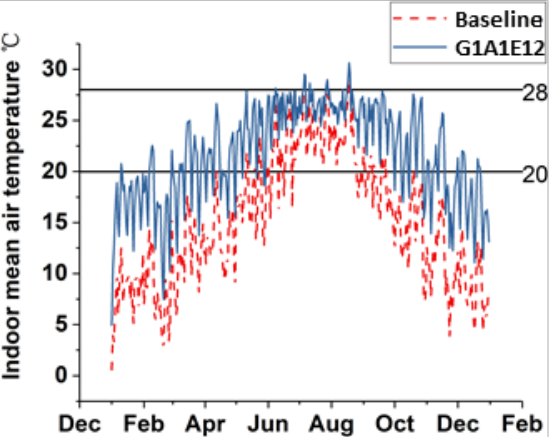

(c) Attic floor

Fig.11 Indoor mean air temperature for retrofit combination G1A1E12

Fig. 12 indicates indoor mean air temperature for retrofit combination G1A3E12 from ground floor to attic floor, which is compared with the baseline. As one of the cost-effective combinations with the space reduction rate of $1.3 \%$, the ground floor, had an indoor maximum and minimum temperatures of $6.4^{\circ} \mathrm{C}-27.9^{\circ} \mathrm{C}, 4.6^{\circ} \mathrm{C}-28.9^{\circ} \mathrm{C}$ and $2.8^{\circ} \mathrm{C}-30^{\circ} \mathrm{C}$, respectively, which is on average $2.2^{\circ} \mathrm{C}$ higher in winter as compared with the baseline.

From June to September, the temperature ranges of the ground floor, first floor and attic floor are $16.5^{\circ} \mathrm{C}-27.9^{\circ} \mathrm{C}, 19^{\circ} \mathrm{C}-28.9^{\circ} \mathrm{C}$ and $19^{\circ} \mathrm{C}-30^{\circ} \mathrm{C}$, respectively, which resulted in overheating of on the first floor $\left(0.9^{\circ} \mathrm{C}\right)$ and on the attic floor $\left(2.0^{\circ} \mathrm{C}\right)$. In comparison with the previous two combinations (G1A3E3 and G1A1E12), the summer overheating risk for G1A3E12 is much lower. In the ground floor and first floor, the highest indoor mean temperature is close to the standard summer temperature of $28^{\circ} \mathrm{C}$.

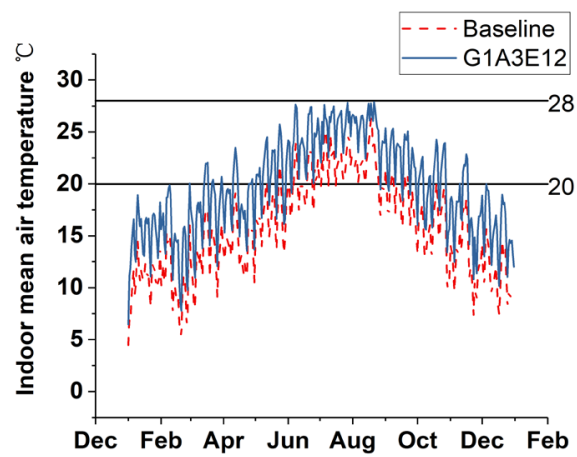

(a) Ground floor

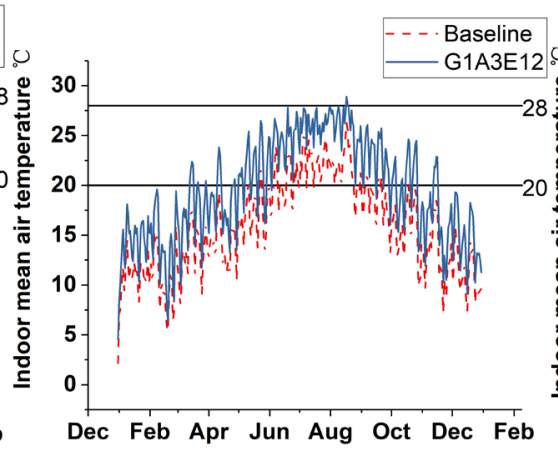

(b) First floor

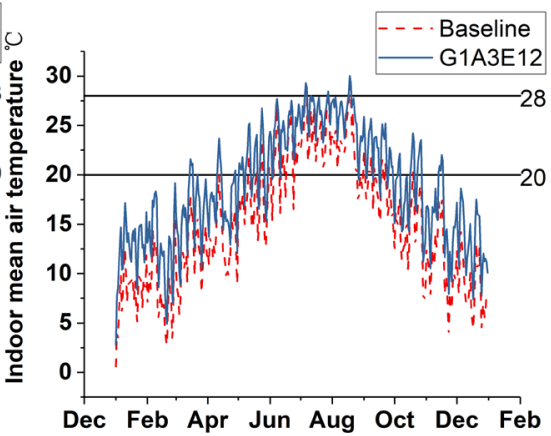

(c) Attic floor

Fig.12 Indoor mean air temperature for retrofit combination G1A3E12 
Fig. 13 shows the comparisons of indoor maximum air temperature for the three retrofit combinations, together with the baseline scenario. It could be observed that, in general, after the retrofit, the winter indoor temperature is significantly increased, and the period when the indoor temperature is above the standard recommended winter comfort temperature $\left(20^{\circ} \mathrm{C}\right)$ has been greatly extended to more than 5 months (from October to March), in comparison to less than 1 month for the baseline scenario. It can be observed that the maximum summer temperature increases only slightly above standard summer comfort temperature $\left(28^{\circ} \mathrm{C}\right)$ after the retrofit.

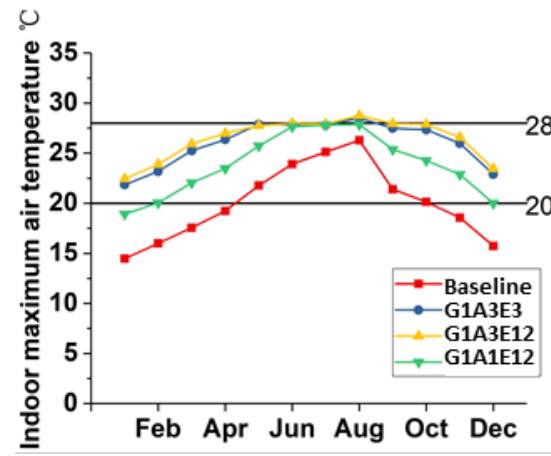

(a) Ground floor

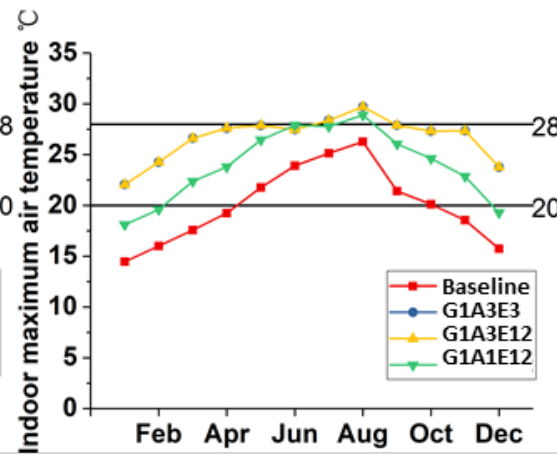

(b) First floor

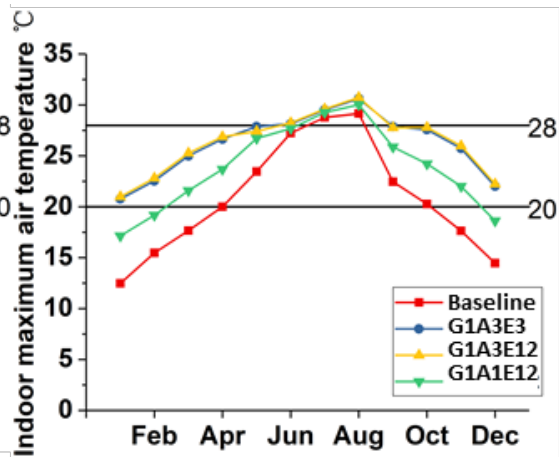

(c) Attic floor

Fig.13 Comparisons of indoor maximum air temperatures for the selected three combinations

The heating/cooling degree days, the maximum and minimum temperature in summer and winter for baseline and the selected retrofit combinations (G1A3E3, G1A1E12 and G1A3E12) have been listed in Table 9. The IHDD of three passive retrofit combinations on the ground floor has been reduced to $244.3^{\circ} \mathrm{C} \cdot \mathrm{d}, 318.8^{\circ} \mathrm{C} \cdot \mathrm{d}$ and $750.4^{\circ} \mathrm{C} \cdot \mathrm{d}$, respectively corresponding to $85.7 \%, 81.4 \%$ and $56.2 \%$ reduction in comparison with the baseline case. For the first floor, G1A3E3, G1A1E12 and G1A3E12 lead to IHDD of $264.5^{\circ} \mathrm{C} \cdot \mathrm{d}, 332.3^{\circ} \mathrm{C} \cdot \mathrm{d}$ and $877.3^{\circ} \mathrm{C} \cdot \mathrm{d}$, in comparison with that for baseline scenario (IHDD of $\left.1714.2^{\circ} \mathrm{C} \cdot \mathrm{d}\right)$. For the attic floor, as compared with IHDD of the baseline $\left(2091.2^{\circ} \mathrm{C} \cdot \mathrm{d}\right)$, the IHDD of these three combinations is reduced by $79.9 \%, 78.0 \%$ and $47.2 \%$, respectively.

It is also important to point out that, after adopting passive building retrofit strategies, a compromise between the reduced heating demand and the increased cooling demand is proposed. For the selected three retrofit combinations, the weighting between heating and cooling demand could be represented by the ratio between ICDD and IHDD (ICDD/IHDD) for each combination. For instance, ICDD/IHDD for baseline (summer maximum temperature of $29.2^{\circ} \mathrm{C}$ ), and the combination of G1A3E3 
(summer maximum temperature of $30.7^{\circ} \mathrm{C}$ ), G1A1E12 (summer maximum temperature of $30.6^{\circ} \mathrm{C}$ ) and G1A3E12 (summer maximum temperature of $30.7^{\circ} \mathrm{C}$ ) are $0.14 \%, 2.72 \%, 2.24 \%$ and $0.55 \%$, respectively. This indicates that, for each combination, the amount of heating demand reduction for the post-retrofit scenario is drastically more significant than the corresponding increase in the cooling demand. It should be noticed that natural ventilation such as opening windows is not used during the simulation, which results in the peak room temperature higher than the comfort level. As shown in Figure 10-13, although the cooling load in summer is very low, it is suggested to incorporate a ventilation method to enhance the indoor thermal comfort level. In order to reduce the summer overheating in passive retrofitted dwellings, it is suggested to introduce a small mechanical ventilation device over the windows and the wall sides or natural ventilation strategies.

Table 9 Heating/cooling degree days, maximum and minimum temperature in summer and winter for baseline and the selected retrofit combinations

\begin{tabular}{|c|c|c|c|c|c|c|c|c|}
\hline Combinations & & & Baseline & & & & 1A3E3 & \\
\hline Parameters & $\begin{array}{l}\text { IHDD } \\
\left({ }^{\circ} \mathrm{C} \cdot\right. \\
\text { days) }\end{array}$ & $\begin{array}{l}\text { ICDD } \\
\left({ }^{\circ} \mathrm{C} \cdot\right. \\
\text { days })\end{array}$ & $\begin{array}{c}\text { Summer } \\
\text { Maximum } \\
\text { temperature } \\
\left({ }^{\circ} \mathrm{C}\right)\end{array}$ & $\begin{array}{c}\text { Winter } \\
\text { Minimum } \\
\text { temperature } \\
\left({ }^{\circ} \mathrm{C}\right)\end{array}$ & $\begin{array}{l}\text { IHDD } \\
\left({ }^{\circ} \mathrm{C} \cdot\right. \\
\text { days) }\end{array}$ & $\begin{array}{l}\text { ICDD } \\
\left({ }^{\circ} \mathrm{C} \cdot\right. \\
\text { days })\end{array}$ & $\begin{array}{c}\text { Summer } \\
\text { Maximum } \\
\text { temperature } \\
\left({ }^{\circ} \mathrm{C}\right)\end{array}$ & $\begin{array}{c}\text { Winter } \\
\text { Minimum } \\
\text { temperature } \\
\left({ }^{\circ} \mathrm{C}\right)\end{array}$ \\
\hline Ground floor & 1711.9 & 0.0 & 26.3 & 4.5 & 318.8 & 0.5 & 28.5 & 7.5 \\
\hline First floor & 1714.2 & 0.0 & 26.3 & 2.2 & 332.3 & 2.3 & 29.5 & 6.4 \\
\hline Attic floor & 2091.6 & 2.9 & 29.2 & 0.6 & 460.6 & 10.3 & 30.6 & 4.9 \\
\hline Combinations & & & S1A1E12 & & & & A3E12 & \\
\hline Parameters & $\begin{array}{l}\text { IHDD } \\
\left({ }^{\circ} \mathrm{C} \cdot\right. \\
\text { days })\end{array}$ & $\begin{array}{c}\text { ICDD } \\
\left({ }^{\circ} \mathrm{C} \cdot\right. \\
\text { days })\end{array}$ & $\begin{array}{c}\text { Summer } \\
\text { Maximum } \\
\text { temperature } \\
\left({ }^{\circ} \mathrm{C}\right)\end{array}$ & $\begin{array}{c}\text { Winter } \\
\text { Minimum } \\
\text { temperature } \\
\left({ }^{\circ} \mathrm{C}\right)\end{array}$ & $\begin{array}{l}\text { IHDD } \\
\left({ }^{\circ} \mathrm{C} \cdot\right. \\
\text { days })\end{array}$ & $\begin{array}{c}\text { ICDD } \\
\left({ }^{\circ} \mathrm{C} \cdot\right. \\
\text { days })\end{array}$ & $\begin{array}{c}\text { Summer } \\
\text { Maximum } \\
\text { temperature } \\
\left({ }^{\circ} \mathrm{C}\right)\end{array}$ & $\begin{array}{c}\text { Winter } \\
\text { Minimum } \\
\text { temperature } \\
\left({ }^{\circ} \mathrm{C}\right)\end{array}$ \\
\hline Ground floor & 244.3 & 0.8 & 28.8 & 8.0 & 750.4 & 0.0 & 27.9 & 6.4 \\
\hline First floor & 264.5 & 3.4 & 29.7 & 6.8 & 877.3 & 1.0 & 28.9 & 4.6 \\
\hline Attic floor & 419.8 & 11.4 & 30.7 & 5.1 & 1104.7 & 6.1 & 30.0 & 2.8 \\
\hline
\end{tabular}




\section{Conclusion and Future Works}

This paper presents a comprehensive assessment for a historical building renovation to evaluate the performance of selected retrofit measures and their combinations from the perspectives of energy saving, cost-effectiveness and thermal comfort improvements. In response to the three research questions listed in section 2.1, the following conclusions can be drawn:

1) For the 63 defined advanced and traditional retrofit combinations, about $28.5 \%$ of them are able to achieve "Deep Renovation", with more than $60 \%$ energy reduction after retrofit intervention. The benefits of applying advanced retrofit combinations over traditional ones are apparent: $66.7 \%$ of advanced retrofit combinations could achieve at least $60 \%$ energy reduction while none of the traditional retrofit combinations is able to reach this level. About $22.8 \%$ of traditional combinations can achieve a maximum $50-60 \%$ energy saving. In general, the proposed passive retrofit combinations can improve the EPC rating from $G$ grade (baseline building) to $E$ and $D$ grade. Considering the defined space volume reduction rates of $5.2 \%, 2.6 \%$ and $1.3 \%$, the maximum energy saving occurred in the combination of G5A1E1 (66.8\% of energy reduction to $\left.99.61 \mathrm{kWh} / \mathrm{m}^{2}\right)$, G5A1E2 $\left(64.7 \%\right.$ of energy reduction to $\left.105.87 \mathrm{kWh} / \mathrm{m}^{2}\right)$ and $\mathrm{G} 5 \mathrm{~A} 1 \mathrm{E} 3(61.2 \%$ of energy reduction to $116.49 \mathrm{kWh} / \mathrm{m}^{2}$ ). It could be further concluded that by incorporating double vacuum glazing with lowE coating (G5) and gypsum air infiltration reduction (A1), the maximum energy saving potential could be achieved.

2) From the economic benefits point of view, for the 3 defined space volume reduction rates, the decrease of space reduction rate will lead to lower investment costs with a shorter payback period, although, the energy reduction potential is also reduced. For instance, under space reduction rate $V r=5.2 \%$, the traditional retrofit combinations with the average energy-saving potential of $48.5 \%$, are more cost-effective than the advanced combinations with the average energy-saving potential of $63.3 \%$. The discounted payback period of the advanced retrofit combinations is 17 years more than the traditional retrofit combinations. Under $V r=2.6 \%$, the traditional retrofit combinations with the average energy-saving potential of $43.3 \%$, have almost the same cost-effectiveness as compared with the advanced combinations, with an average energy-saving potential of $59.0 \%$. The discounted payback period of the advanced retrofit combinations was 12 years more than the traditional retrofit 
combinations. While decreasing $V r$ to $1.3 \%$ led to an increased cost-effectiveness of the advanced retrofit combinations, higher than that of the traditional retrofit combinations. The avragely discounted payback period of the traditional retrofit combinations was 8 years more than the advanced retrofit combinations.

3) In order to separately and jointly evaluate the energy-saving and cost-effectiveness of the selected combinations, three levels of optimisation categories have been considered. It can be concluded that for $V r=1.3 \%$, are G1A3E3, G1A3E12 and G1A1E12 combinations provided the maximum energy saving, highest cost-effectiveness and energy-cost combination, respectively. When $V r$ increases to $5.2 \%, \mathrm{G} 5 \mathrm{~A} 1 \mathrm{E} 10, \mathrm{G} 1 \mathrm{~A} 3 \mathrm{E} 13$, and $\mathrm{G} 1 \mathrm{~A} 1 \mathrm{E} 10$ would be the best combinations that respectively satisfy the three defined categories.

4) From the indoor comfort point of view, for the proposed passive retrofit combinations, the increase of $V r$ could significantly increase the winter indoor temperature. However, this is accompanied by potential summer overheating issues, subjected to the increase of the insulation thickness. For instance, the most favourable energy-cost combination of $\mathrm{G} 1 \mathrm{~A} 1 \mathrm{E} 12$ shows a $4.3^{\circ} \mathrm{C}$ temperature increase in winter and $2.6^{\circ} \mathrm{C}$ temperature increase in summer. This summer overheating phenomenon is relatively insignificant, with maximum cooling degree days in the attic floor increased only from $2.9^{\circ} \mathrm{C}$ day (Baseline) to $10.3^{\circ} \mathrm{C}$ day (G1A3E3).

For the Victorian house evaluated in the present work, to avoid large space volume reduction, a $1.3 \%$ space volume reduction rate is recommended, leading to $51.8 \%$ of primary energy reduction, initial investment cost of $£ 144.71 / \mathrm{m}^{2}$ and a discounted payback periods of 18 years. The recommended passive retrofit combination is the integration of vacuum insulation windows, Gypsum air infiltration reduction and $2 \mathrm{~cm}$ thickness of PIR panels. It should be noted that the research presented in this study potentially has the following limitations due to some of the assumptions in the simulation model: 1) natural ventilation is not considered in the IES VE model; 2) the current model will not be able to predict the building fabric temperature changes (with tiny percentage changes) due to the fact that the proposed interior passive insulation layer will be added to the existing wall. It might be worthwhile analysing the possibility of water condensation and its impacts on the building structure when the penetrating air tempreture drops below the dew point temperature. 
In addition, there are several limitations associated with the proposed technologies which are not taken into account in the present work and could be explored later. For example, the influence of the internal insulation on the fabric temperature, the quality of the measure over time, support pillars of the vacuum insulation windows, thermal bridging, etc.

The findings from this research can provide valuable guidance for similar historical building renovations in northern Europe (cold climate), from an energy-efficiency, cost-effectiveness and thermal comfort perspecitve. For existing historical buildings in Southern Europe (warm climate), when adopting the proposed comprehensive passive retrofit strategy, the impact of increased cooling demand could be potentially more significant compared with the case study presented in this research. Therefore, when adopting the passive retrofit measures in a warm climate, ventilation units are highly recommended with either natural or mechanical method. Further study could be dedicated to investigating the impact of climatic conditions on the proper selection of passive building retrofit strategies. The outcomes of this study can be used to define a seires of cost-effective retrofit combinations that could be applied to a significant portion of the domestic housing sector in the UK and Europe. Green Building Associations (e.g. UK Green Building Council, Association for Environment Conscious Building) and policy makers can adopt this research to refine their energy decarbonisation strategies and optimise the energy efficiency of their property portfolios to help address fuel poverty issue, improve occupancy's comfort level and contribute to the Europe's 2050 net zero goals.

\section{Reference}

1. The Paris Agreement -legally binding versus non-legally binding instruments. 12 December 2015.

2. A Clean Planet for all - A European strategic long-term vision for a prosperous, modern, competitive and climate neutral economy, E. COMMISSION, Editor. 28/11/2018.

3. UK becomes first major economy to pass net zero emissions law. 2019, Department for Business, Energy \& Industrial Strategy: GOV.UK.

4. Global Commission for Urgent Action on Energy Efficiency, in IEA's 4th annual Global Conference on Energy Efficiency. 24 June 2019: Dublin, Ireland.

5. EUROPEAN COMMISSION, Directive 2010/31/EU of 19 May 2010 on the energy performance of buildings. 2010.

6. Ministry of Housing, C.L.G., English Housing Survey 2018 to 2019: headline report, N. Statistics, Editor. 2019. 
7. Lowe, R. and L.F. Chiu, Innovation in deep housing retrofit in the United Kingdom: The role of situated creativity in transforming practice. Energy Research \& Social Science, 2020. 63: p. 101391.

8. UK housing: Fit for the future? 2019, Committee on Climate Change.

9. La Fleur, L., P. Rohdin, and B. Moshfegh, Energy Renovation versus Demolition and Construction of a New Building-A Comparative Analysis of a Swedish Multi-Family Building. Energies, 2019. 12: p. 2218.

10. Godwin, P.J., Building Conservation and Sustainability in the United Kingdom. Procedia Engineering, 2011. 20: p. 12-21.

11. Whitman, C., Prizeman, Oriel Elizabeth Clare and Lacey-Barnacle, Max, Correlating maintenance, energy efficiency and fuel poverty for traditional buildings in the UK. 2016: Welsh School of Architecture, Cardiff University.

12. Marshall, J.W., Ian, The Victorian House. 1986, London: Sidgwick and Jackson Limited.

13. Arumägi, E. and T. Kalamees, Analysis of energy economic renovation for historic wooden apartment buildings in cold climates. Applied Energy, 2014. 115: p. 540-548.

14. Cho, H.M., et al., Hygrothermal and energy retrofit planning of masonry façade historic building used as museum and office: A cultural properties case study. Energy, 2020. 201: p. 117607.

15. Galatioto, A., G. Ciulla, and R. Ricciu, An overview of energy retrofit actions feasibility on Italian historical buildings. Energy, 2017. 137: p. 991-1000.

16. Bottino-Leone, D., et al., Evaluation of natural-based internal insulation systems in historic buildings through a holistic approach. Energy, 2019. 181: p. 521-531.

17. Lo Basso, G., et al., Hybrid systems adoption for lowering historic buildings PFEC (primary fossil energy consumption) - A comparative energy analysis. Renewable Energy, 2018. 117: p. 414-433.

18. Gustafsson, S.I. and M. Bojic, Optimal heating-system retrofits in residential buildings. Energy, 1997. 22(9): p. 867-874.

19. Ciulla, G., A. Galatioto, and R. Ricciu, Energy and economic analysis and feasibility of retrofit actions in Italian residential historical buildings. Energy and Buildings, 2016. 128: p. 649-659.

20. Chen, X., et al., Multi-Criteria Assessment Approach for a Residential Building Retrofit in Norway. Energy and Buildings, 2019: p. 109668.

21. Abdul Mujeebu, M., N. Ashraf, and A. Alsuwayigh, Energy performance and economic viability of nano aerogel glazing and nano vacuum insulation panel in multi-story office building. Energy, 2016. 113: p. 949-956.

22. Berardi, U. and R.H. Nosrati, Long-term thermal conductivity of aerogel-enhanced insulating materials under different laboratory aging conditions. Energy, 2018. 147: p. 1188-1202.

23. Huang, Y. and J.-1. Niu, Application of super-insulating translucent silica aerogel glazing system on commercial building envelope of humid subtropical climates - Impact on space cooling load. Energy, 2015. 83: p. 316-325.

24. Chen, Z., et al., Preparation and characterization of vacuum insulation panels with superstratified glass fiber core material. Energy, 2015. 93: p. 945-954.

25. Mao, S., et al., Prediction of thermal performance of vacuum insulation panels (VIPS) with micro-fiber core materials. Materials Today Communications, 2020. 22: p. 100786.

26. Biswas, K., et al., Whole building retrofit using vacuum insulation panels and energy performance analysis. Energy and Buildings, 2019. 203: p. 109430.

27. Ariosto, T., A.M. Memari, and R.L. Solnosky, Development of designer aids for energy efficient residential window retrofit solutions. Sustainable Energy Technologies and Assessments, 2019. 33: p. 1-13.

28. Saikia, P., et al., Dynamic optimization of multi-retrofit building envelope for enhanced energy performance with a case study in hot Indian climate. Energy, 2020. 197: p. 117263. 
29. Qu, K., et al., A novel holistic EPC related retrofit approach for residential apartment building renovation in Norway. Sustainable Cities and Society, 2020. 54: p. 101975.

30. Shen, P., et al., Rapid multi-objective optimization with multi-year future weather condition and decision-making support for building retrofit. Energy, 2019. 172: p. 892-912.

31. Streicher, K.N., et al., Cost-effectiveness of large-scale deep energy retrofit packages for residential buildings under different economic assessment approaches. Energy and Buildings, 2020. 215: p. 109870.

32. Zheng, D., L. Yu, and L. Wang, A techno-economic-risk decision-making methodology for large-scale building energy efficiency retrofit using Monte Carlo simulation. Energy, 2019. 189: p. 116169.

33. Galatioto, A., et al., Energy and economic analysis on retrofit actions for Italian public historic buildings. Energy, 2019. 176: p. 58-66.

34. Copiello, S., L. Gabrielli, and P. Bonifaci, Evaluation of energy retrofit in buildings under conditions of uncertainty: The prominence of the discount rate. Energy, 2017. 137: p. 104117.

35. Rodrigues, C. and F. Freire, Adaptive reuse of buildings: Eco-efficiency assessment of retrofit strategies for alternative uses of an historic building. Journal of Cleaner Production, 2017. 157: p. 94-105.

36. Wang, R., S. Lu, and W. Feng, A three-stage optimization methodology for envelope design of passive house considering energy demand, thermal comfort and cost. Energy, 2020. 192: p. 116723.

37. Tahsildoost, M. and Z. Zomorodian, Energy, carbon, and cost analysis of rural housing retrofit in different climates. Journal of Building Engineering, 2020. 30: p. 101277.

38. Ghazi Wakili, K., et al., Energy efficient retrofit of a prefabricated concrete panel building (Plattenbau) in Berlin by applying an aerogel based rendering to its façades. Energy and Buildings, 2018. 165: p. 293-300.

39. Elsharkawy, H. and S. Zahiri, The significance of occupancy profiles in determining post retrofit indoor thermal comfort, overheating risk and building energy performance. Building and Environment, 2020: p. 106676.

40. Amiri Fard, F. and F. Nasiri, A bi-objective optimization approach for selection of passive energy alternatives in retrofit projects under cost uncertainty. Energy and Built Environment, 2020. 1(1): p. 77-86.

41. Ascione, F., et al., Retrofit of villas on Mediterranean coastlines: Pareto optimization with a view to energy-efficiency and cost-effectiveness. Applied Energy, 2019. 254: p. 113705.

42. Europe's Buildings under the-A Country-by-Country Review of the Energy Performance of Buildings, B.P.I.E. (BPIE), Editor. 2011: BPIE: Brussels, Belgium.

43. EnergyPlus. 2019; Available from: https://energyplus.net/.

44. De Simone, M., et al., Reference procedures for obtaining occupancy profiles in residential buildings. 2018.

45. Sandels, C., J. Widén, and L. Nordström. Simulating occupancy in office buildings with nonhomogeneous Markov chains for Demand Response analysis. in 2015 IEEE Power \& Energy Society General Meeting. 2015.

46. Duarte, C., K. Wymelenberg, and C. Rieger, Revealing occupancy patterns in an office building through the use of occupancy sensor data. Energy and Buildings, 2013. 67: p. 587595.

47. Despenic, M., et al., Lighting preference profiles of users in an open office environment. Building and Environment, 2017. 116: p. 89-107.

48. Menezes, A.C., et al., Estimating the energy consumption and power demand of small power equipment in office buildings. Energy and Buildings, 2014. 75: p. 199-209.

49. Gillott, M.C., et al., Improving the airtightness in an existing UK dwelling: The challenges, the measures and their effectiveness. Building and Environment, 2016. 95: p. 227-239. 
50. Jokisalo, J., et al., Building leakage, infiltration, and energy performance analyses for Finnish detached houses. Building and Environment, 2009. 44(2): p. 377-387.

51. Jayamalathi, P.S.C.S., Performance improvement study of solar water heating system. ARPN Journal of Engineering and Applied Sciences, January 2012.

52. Makrodimitri, M., Energy efficient refurbishment of old listed dwellings

The case of Victorian housing stock. Consilience, 2010(4): p. 33-59.

53. Wang, Y., et al., Thermal conductivity, structure and mechanical properties of konjac glucomannan/starch based aerogel strengthened by wheat straw. Carbohydrate Polymers, 2018. 197: p. 284-291.

54. Katsura, T., et al., Thermal performance analysis of a new structured-core translucent vacuum insulation panel in comparison to vacuum glazing: Experimental and theoretically validated analyses. Solar Energy, 2020. 199: p. 326-346.

55. Somasundaram, S., S.R. Thangavelu, and A. Chong, Improving building efficiency using lowe coating based retrofit double glazing with solar films. Applied Thermal Engineering, 2020. 171: p. 115064.

56. Lee, C. and J. Won, Analysis of combinations of glazing properties to improve economic efficiency of buildings. Journal of Cleaner Production, 2017. 166: p. 181-188.

57. PLACOTHERM® V. Available from: https://www.placo.es/systems/fachadas/placothermr-v.

58. Stormguard Brush Pile White 10m. Available from: https://www.toolstation.com/stormguardbrush-

pile/p23638?store=N1\&utm_source=googleshopping\&utm_medium=feed\&utm_campaign= googleshoppingfeed\&gclid=CjwKCAjw26H3BRB2EiwAy32zhSMmVCHkoL9GvX ZOT Gv6dSCnkbT26kZA8KWcjYty1iS--zuv0OV8hoCDfIQAvD BwE.

59. EXPANDING FOAM TAPE DELIVERED NEXT DAY $\mid$ BBA APPROVED. 16th June 2020]; Available

from: https://www.expandingfoamtape.co.uk/products/exp6102612?utm_medium=cpc\&utm_sour ce=Facebook\&utm campaign $=$ FB $\% 20$ Dynamic $\% 20$ Remarketing\&cmp $\mathrm{id}=1724280400 \& \mathrm{adg} \mathrm{id}=70379647354 \& \mathrm{kwd}=\&$ device $=\mathrm{c} \& \mathrm{gclid}=\mathrm{CjwKC}$ Ajw26H3BRB2EiwAy32zhc9kIyUBkBGUIsH1t4zDBrWldp1Jyg11Pck_dI5SVIDCFCBvNzCuBoC0Z4QAvD_BwE.

60. Vacutherm Vacupor NT-B2 16th June 2020]; Available from: https://www.insulationsuperstore.co.uk/product/vacutherm-vacupor-nt-b2-vacuuminsulated-panel-12m-x-500mm-x-20mm.html.

61. Spacetherm Wall Liner. 16th June 2020]; Available from: https://www.proctorgroup.com/products/spacetherm.

62. Wang, Y., et al., The advances of polysaccharide-based aerogels: Preparation and potential application. Carbohydrate Polymers, 2019. 226: p. 115242.

63. Kingspan TP10 PIR Insulation. Kingspan TP10 PIR Insulation 1200 x 2400 x 25mm; Available from: https://www.cutpriceinsulation.co.uk/products/kingspan-tp10-pir-insulation$1200-\mathrm{x}-2400-\mathrm{x}-$

$25 \mathrm{~mm}$ ?variant $=16705201831993 \&$ currency $=$ GBP\&utm source $=$ google $\& u t m$ medium $=c p c$ \&utm campaign=google+shopping\&gclid=CjwKCAjw26H3BRB2EiwAy32zhQwP5aoadff NbUbchTlMn311A6mpwG2QuQh4TpGox5Dm2Jdt64MPNBoCIZoQAvD_BwE.

64. Knauf Earthwool. Available from: https://www.condell-ltd.com/knauf-earthwool-loft-roll44-combi-cut-200mm-5-

93m2?gclid=CjwKCAjw26H3BRB2EiwAy32zhWVcDm NkA98r_U18Q3VGdpqap5oqR f3W IuC0aLIPEfazComck5xoCy34QAvD BwE.

65. REPORT FROM THE COMMISSION TO THE EUROPEAN PARLIAMENT AND THE COUNCIL: Financial support for energy efficiency in buildings in COM(2013) 225 final, E. COMMISSION, Editor. 2013: Brussels. 
66. D'Agostino, D., P. Zangheri, and L. Castellazzi, Towards Nearly Zero Energy Buildings in Europe: A Focus on Retrofit in Non-Residential Buildings. Energies, 2017. 10: p. 117.

67. Bonazzi, G. and M. Iotti, Evaluation of Investment in Renovation to Increase the Quality of Buildings: A Specific Discounted Cash Flow (DCF) Approach of Appraisal. Sustainability, 2016. 8: p. 268.

68. Dufton, A.F., Degree days. JIHVE, 1934. 2.

69. D'Amico, A., et al., Building energy demand assessment through heating degree days: The importance of a climatic dataset. Applied Energy, 2019. 242: p. 1285-1306. 